\section{URBANISMO VERSUS PlaneJAMENTO URBANO?}

\author{
JoÃo Farias Rovati
}

R E S U M O O uso dos termos urbanismo e planejamento urbano é frequentemente ambiguo. $O$ artigo examina como se expressa essa ambiguidade na pós-graduação brasileira. A hipótese é que o problema obscurece a existência de campos epistêmicos distintos, gera divergências incongruentes e dificulta a cooperação entre conhecimento, saberes e profissöes que de fato não se opóem, mas são complementares.

P A L A V R A S - C H A V E Urbanismo, planejamento urbano, campos epistêmicos, conhecimentos, profissóes.

\section{INTRODUÇÃO}

No Brasil, o emprego das palavras urbanismo e planejamento urbano quase sempre demanda algum esclarecimento. ${ }^{1}$ Para uns, esses termos contemplam profissóes e conhecimentos distintos; para outros, remetem aos mesmos saberes. Mas essa ambiguidade terminológica-conceitual não é "brasileira". Com maior ou menor ênfase, aparece também em países com os quais mantemos estreitas relaçóes de intercâmbio. ${ }^{2}$ Assim, às nossas dificuldades nesse terreno somam-se àquelas relacionadas ao debate conceitual existente fora do país. O problema não é retórico. Por exemplo, visóes conceituais divergentes podem confundir o escopo de políticas públicas ou de programas de ensino. Trata-se de um processo de natureza circular: a incerteza terminológicaconceitual reflete-se no trabalho dos urbanistas/planejadores; e as múltiplas atividades que desenvolvem dificultam o enquadramento teórico-conceitual dos termos.

Este artigo $^{3}$ examina como essa incerteza se expressa na pós-graduação brasileira, lugar onde os conceitos são objeto permanente de investigação. Os programas de pósgraduação, ao reunirem pesquisadores experientes e urbanistas/planejadores em busca de aperfeiçoamento, representam uma face importante do exercício do urbanismo/ planejamento no país.

Uma hipótese orientou nosso estudo: as incertezas que envolvem a utilização dos termos urbanismo e planejamento urbano obscurecem a existência de campos epistêmicos distintos. ${ }^{4} \mathrm{Um}$ desses campos tem clara vocação disciplinar e contempla essencialmente a tomada de decisões relativas à concepção arquitetural; reivindica-se aí uma "competência para o projeto". O outro integra conhecimentos disciplinares diversos (economia, geografia e sociologia, entre outros) e contempla essencialmente a tomada de decisôes relativas à elaboraçáo (ou encomenda) e gestão de planos, programas e projetos - inclusive, mas não necessariamente, de natureza arquitetônica; reivindica-se aí uma "competência para o planejamento e a gestáo". De uma parte, o objeto da ação/ reflexão é, antes de tudo, um artefato ou uma edificação, cuja construção ou reforma demanda a mediação de plantas, elevaçóes, cortes e outros desenhos prospectivos
1 As regras gramaticais determinam o uso de letras maiúsculas quanto há referência a ramos do conhecimento. No presente texto não aplicaremos essa regra aos termos urbanismo e planejamento urbano, nem a outros ramos do conhecimento. Esse critério evidentemente não será aplicado aos textos citados, que serão reproduzidos tal qual aparecem escritos em suas fontes. O leitor notará que somente alguns programas obedecem (e às vezes ocasionalmente) a referida regra.

2 Em 2004, o governo francês encomendou um estudo sobre as características da profissão na Alemanha, Espanha, Itália, Holanda e Inglaterra; parte importante desse estudo trata da questão terminológica; ver Robert Laugier (2005). Em artigo publicando recentemente, Jean -Louis Cohen (2012) referese à dificuldade de discernir as peculiaridades nacionais e linguísticas que envolvem o emprego de termos aparentemente idênticos, porém distintos, como "urbanismo". Criado em 2012 por um grupo de jovens urbanistas, o blogue jesuisurbaniste.fr (<http://jesuisurbaniste.fr/>) critica a atribuição do Grande Premio de Urbanismo, instituído pelo governo francês em 1989, a arquitetos.

3 A pesquisa cujos resultados são apresentados adiante integra o Plano de Trabalho do Estágio Sênior realizado pelo autor na Universidade $\mathrm{Na}$ cional de General Sarmiento (Buenos Aires, Argentina), graças ao apoio da Universidade Federal do Rio Grande do Sul (UFRGS) e da Coordenação de Aperfeiçoamento de Pessoal de Nível Superior (CAPES), no período agosto-2012/julho-2013.

4 Esta hipótese não tem a pretensão de originalidade. Outros pesquisadores, dentro e fora do Brasil, têm explorado este ponto de vista; ver, por exemplo: Marcelo Lopes de Souza (2002), Alicia Novick (2007), Ana Maria Rigoti (2005) e Afonso Raposo (2006). 
50 conceito tem sido objeto de diferentes usos e interpretações e, da maneira como foi proposto por Bourdieu, integra um sistema conceitual complexo, exposto, complementado e modificado em diversas obras do autor. No presente artigo, utilizase esse conceito de maneira bastante aberta e simplificada. Ressalte-se que o conceito tem sido empregado em inúmeros trabalhos (artigos, dissertações, teses) relacionados ao urbanismo/planejamento; ver, por exemplo, Jeová Dias Martins (2006).

6 Tradução livre do autor (JFR).

7 É importante ressaltar que as denominações das áreas não são criações "da CAPES" ou de seus dirigentes, mas das instituições e pesquisadores que a integram e constituem.

8 As ações e argumentos que acompanharam a criação dessas duas áreas constituem uma excelente fonte de pesquisa e, por si só, mereceriam ser estudados. Registre-se que, até 1993, ano em que foi criada a área "Arquitetura e Urbanismo", diversos programas que hoje pertencem a essa área integravam a área "Planejamento Urbano e Regional".

9 Cadernos disponíveis em: $<$ http://conteudoweb.capes. gov.br/conteudoweb/CadernoAvaliacaoServlet?acao=filtraArquivo\&ano $=2009 \&$ codigo_ies $=\& a r e a=30>$ Acessado em $12 / 05 / 2013$ precisos. De outra, o objeto da ação/reflexão é, antes de tudo, um processo social em desenvolvimento, cuja gestão no presente demanda a mediação de hipóteses sobre o seu futuro. De um lado, encontra-se um processo social relativo à constituição edilícia da cidade, de outro, um processo relacionado ao funcionamento e à transformação da organização social urbana. Os agentes e instituiçóes do urbanismo/planejamento transitariam por esses campos, os quais, embora próximos e complementares, seriam presididos por epistemologias de natureza diversa.

O espaço de interação entre os campos sumariamente descritos acima parece constitutivo da experiência do urbanismo/planejamento. E deve ser investigado justamente porque, nas ciências sociais, os conceitos não são propriedade das coisas, mas esquemas de inteligibilidade relacionados às singularidades dos contextos sociais e históricos nos quais são concebidos. A palavra campo, nesse caso, relaciona-se ao conceito proposto por Pierre Bourdieu', evocando a existência de "espaços" (geográficos e sociais) relativamente autônomos, constituídos segundo certas regras e instâncias de legitimação, "de tal maneira que, quanto mais próximos estiverem os agentes, grupos ou instituiçôes ali situados, mais propriedades terão em comum; e, quanto mais afastados, menos propriedades terão em comum"6 (Bourdieu, 1987, p. 151). Aplicando-se essa ideia ao problema que nos interessa, estariam mais próximos entre si, no plano conceitual, os urbanistas/planejadores que trabalham em organismos municipais, ou como docentes em cursos de arquitetura e urbanismo, ou que associam suas práticas a uma abordagem interdisciplinar, ou a uma determinada causa, etc. Esses grupos, mais ou menos homogêneos, colaborando ou concorrendo, articulariam relaçóes de poder dinâmicas; ao longo do tempo, ao ganharem novos contornos, essas relaçóes poderiam redefinir ou até dissolver os campos constituídos.

\section{CORPUS}

O problema que nos ocupa aparece desde logo nas próprias denominaçôes das áreas de conhecimento do "sistema CAPES". 7 Encontram-se programas cujo trabalho está relacionado ao urbanismo/planejamento em diferentes áreas. Por exemplo: questóes relativas ao saneamento urbano, como inexistência ou precariedade de redes de esgotos, estão na origem da experiência do urbanismo/planejamento no Brasil e, até hoje, têm grande relevância na problemática urbana brasileira. Porém, os programas de pós-graduação (de saneamento, engenharia urbana, engenharia ambiental, etc.) que tratam diretamente desse tema integram a área denominada "Engenharia I".

Nosso estudo limitou-se à análise de programas de áreas que, desde suas denominaçóes, reivindicam uma relação de pertencimento ao urbanismo/planejamento: "Arquitetura e Urbanismo" e "Planejamento Urbano e Regional/Demografia". ${ }^{8}$ Um dos cadernos de indicadores apresentados em 2009 pelos programas integrantes dessas áreas a seus respectivos Comitês de Avaliação, a "Proposta do Programa", é a unidade constitutiva do corpus da pesquisa. Foram excluídos desse corpus os cadernos de onze programas de pós-graduação em Design e Desenho Industrial integrantes da área Arquitetura e Urbanismo e de três programas em Demografia e Estudos Populacionais integrantes da área Planejamento Urbano e Regional/Demografia. Assim, de fato foram analisadas as propostas de dezenove programas vinculados à área Arquitetura e 
Urbanismo ${ }^{9}$, universo de agora em diante identificado pela sigla $\mathrm{AU}$, e de vinte programas vinculados à área Planejamento Urbano e Regional/Demografia,${ }^{10}$ universo de agora em diante identificado pela sigla PUR. As referências a esses cadernos de indicadores serão feitas segundo a relação de siglas informada nos Quadros 1 e 2.

Quadro 1 - AU - Universo de Análise

\begin{tabular}{|c|c|c|}
\hline PROGRAMAS & INSTITUIÇÃO DE ENSINO & CRIAÇÃO \\
\hline PUC-Campinas/PPGU - URBANISMO & $\begin{array}{c}\text { Pontifícia Universidade Católica } \\
\text { de Campinas }\end{array}$ & 1997 \\
\hline $\begin{array}{l}\text { UFAL/PPGAU-DEHA - ARQUITETURA E } \\
\text { URBANISMO - DINÂMICA DO ESPAÇO } \\
\text { HABITADO }\end{array}$ & Universidade Federal de Alagoas & 2003 \\
\hline $\begin{array}{l}\text { UFBA/PPGAU - ARQUITETURA } \\
\text { E URBANISMO }\end{array}$ & Universidade Federal da Bahia & 1983 \\
\hline $\begin{array}{l}\text { UFES/PPGAU - ARQUITETURA } \\
\text { E URBANISMO }\end{array}$ & Universidade Federal do Espírito Santo & 2007 \\
\hline UFF/PPGAU - ARQUITETURA E URBANISMO & Universidade Federal Fluminense & 2002 \\
\hline $\begin{array}{l}\text { UFMG/NPGAU - ARQUITETURA } \\
\text { E URBANISMO }\end{array}$ & Universidade Federal de Minas Gerais & 1995 \\
\hline $\begin{array}{l}\text { UFPB/PPGAU - ARQUITETURA } \\
\text { E URBANISMO }\end{array}$ & Universidade Federal da Paraíba & 2008 \\
\hline $\begin{array}{l}\text { UFPel/PROGRAU - ARQUITETURA } \\
\text { E URBANISMO }\end{array}$ & Universidade Federal de Pelotas & 2008 \\
\hline UFRGS/PROPAR - ARQUITETURA & $\begin{array}{l}\text { Universidade Federal } \\
\text { do Rio Grande do Sul }\end{array}$ & 1990 \\
\hline UFRJ/PROARQ - ARQUITETURA & $\begin{array}{l}\text { Universidade Federal } \\
\text { do Rio De Janeiro }\end{array}$ & 1985 \\
\hline UFRJ/PROURB - URBANISMO & $\begin{array}{l}\text { Universidade Federal } \\
\text { do Rio de Janeiro }\end{array}$ & 1994 \\
\hline $\begin{array}{l}\text { UFRN/PPGAU - ARQUITETURA } \\
\text { E URBANISMO }\end{array}$ & $\begin{array}{l}\text { Universidade Federal } \\
\text { do Rio Grande do Norte }\end{array}$ & 1999 \\
\hline $\begin{array}{l}\text { UFSC/PósARQ - ARQUITETURA E } \\
\text { URBANISMO - PROJETO E TECNOLOGIA } \\
\text { DO AMBIENTE CONSTRUÍDO }\end{array}$ & $\begin{array}{l}\text { Universidade Federal } \\
\text { de Santa Catarina }\end{array}$ & 2001 \\
\hline $\begin{array}{l}\text { UFSC/PGAU - URBANISMO, HISTÓRIA E } \\
\text { ARQUITETURA DA CIDADE }\end{array}$ & $\begin{array}{l}\text { Universidade Federal } \\
\text { de Santa Catarina }\end{array}$ & 2005 \\
\hline $\begin{array}{l}\text { UnB/PPG-FAU - ARQUITETURA } \\
\text { E URBANISMO }\end{array}$ & Universidade de Brasília & 1995 \\
\hline $\begin{array}{l}\text { UPM/PPGAU - ARQUITETURA } \\
\text { E URBANISMO }\end{array}$ & Universidade Presbiteriana Mackenzie & 2000 \\
\hline $\begin{array}{l}\text { USJT/PGAUR - ARQUITETURA } \\
\text { E URBANISMO }\end{array}$ & Universidade São Judas Tadeu & 2005 \\
\hline $\begin{array}{l}\text { USP-SP/PPGAU - ARQUITETURA } \\
\text { E URBANISMO }\end{array}$ & $\begin{array}{l}\text { Universidade de São Paulo/ } \\
\text { São Paulo }\end{array}$ & 1972 \\
\hline $\begin{array}{l}\text { USP-SC/PPGAU - ARQUITETURA } \\
\text { E URBANISMO }\end{array}$ & $\begin{array}{l}\text { Universidade de São Paulo/ } \\
\text { São Carlos }\end{array}$ & 1971 \\
\hline
\end{tabular}

10 Cadernos disponíveis em: $<$ http://conteudoweb.capes. gov.br/conteudoweb/CadernoAvaliacaoServlet?acao=filtraArquivo\&ano $=2009 \&$ codigo ies $=\& a r e a=29>$ Acessado em $12 / 05 / 2013$ 
FONTE: CAPES; Área Arquitetura e Urbanismo; Cadernos de Indicadores (Ano-base 2009).

Quadro 2 - PUR - Universo de Análise

\begin{tabular}{|c|c|c|}
\hline PROGRAMAS & INSTITUIÇÃO DE ENSINO & CRIAÇÃO \\
\hline $\begin{array}{l}\text { ALFA/PPGDR - DESENVOLVIMENTO } \\
\text { REGIONAL }\end{array}$ & Faculdade Alves Faria & 2007 \\
\hline $\begin{array}{l}\text { FURB/PPGDER - DESENVOLVIMENTO } \\
\text { REGIONAL }\end{array}$ & $\begin{array}{l}\text { Universidade Regional } \\
\text { de Blumenau }\end{array}$ & 2000 \\
\hline $\begin{array}{l}\text { PUC-GO/MDPT - DESENVOLVIMENTO } \\
\text { E PLANEJAMENTO TERRITORIAL }\end{array}$ & $\begin{array}{l}\text { Pontifícia Universidade Católica } \\
\text { de Goiás }\end{array}$ & 2006 \\
\hline PUC-PR/PPGTU - GESTÃO URBANA & $\begin{array}{c}\text { Pontifícia Universidade Católica } \\
\text { do Paraná }\end{array}$ & 2003 \\
\hline $\begin{array}{l}\text { UCAM/PLANEJAMENTO REGIONAL } \\
\text { E GESTÃO DA CIDADE }\end{array}$ & Universidade Cândido Mendes & 2001 \\
\hline $\begin{array}{l}\text { UCSAL/MPA - MESTRADO EM } \\
\text { PLANEJAMENTO AMBIENTAL }\end{array}$ & $\begin{array}{l}\text { Universidade Católica } \\
\text { do Salvador }\end{array}$ & 2007 \\
\hline $\begin{array}{l}\text { UCSAL/PLANEJAMENTO TERRITORIAL } \\
\text { E DESENVOLVIMENTO SOCIAL }\end{array}$ & $\begin{array}{l}\text { Universidade Católica } \\
\text { do Salvador }\end{array}$ & 2005 \\
\hline $\begin{array}{l}\text { UDESC/PLANEJAMENTO TERRITORIAL E } \\
\text { DESENVOLVIMENTO SOCIO-AMBIENTAL }\end{array}$ & $\begin{array}{l}\text { Universidade do Estado } \\
\text { de Santa Catarina }\end{array}$ & 2007 \\
\hline $\begin{array}{l}\text { UEPB/MDR - MESTRADO EM } \\
\text { DESENVOLVIMENTO REGIONAL }\end{array}$ & $\begin{array}{l}\text { Universidade Estadual } \\
\text { da Paraiba }\end{array}$ & 2009 \\
\hline UFPE/MDU - DESENVOLVIMENTO URBANO & $\begin{array}{l}\text { Universidade Federal } \\
\text { de Pernambuco }\end{array}$ & 1975 \\
\hline $\begin{array}{l}\text { UFRGS/PROPUR - PLANEJAMENTO URBANO } \\
\text { E REGIONAL }\end{array}$ & $\begin{array}{l}\text { Universidade Federal } \\
\text { do Rio Grande do Sul }\end{array}$ & 1970 \\
\hline $\begin{array}{l}\text { UFRJ/IPPUR - PLANEJAMENTO URBANO } \\
\text { E REGIONAL }\end{array}$ & $\begin{array}{l}\text { Universidade Federal } \\
\text { do Rio de Janeiro }\end{array}$ & 1972 \\
\hline $\begin{array}{l}\text { UFT/DESENVOLVIMENTO REGIONAL } \\
\text { E AGRONEGÓCIO }\end{array}$ & $\begin{array}{l}\text { Universidade Federal } \\
\text { do Tocantins }\end{array}$ & 2007 \\
\hline $\begin{array}{l}\text { UNAMA/DESENVOLVIMENTO E MEIO } \\
\text { AMBIENTE URBANO }\end{array}$ & Universidade da Amazônia & 2007 \\
\hline UNC/DESENVOLVIMENTO REGIONAL & Universidade do Contestado & 2006 \\
\hline $\begin{array}{l}\text { UNIFACS/PPGDRU - DESENVOLVIMENTO } \\
\text { REGIONAL E URBANO }\end{array}$ & Universidade Salvador & 1999 \\
\hline $\begin{array}{l}\text { UFAP/MESTRADO EM DESENVOLVIMENTO } \\
\text { REGIONAL }\end{array}$ & $\begin{array}{l}\text { Universidade Federal } \\
\text { do Amapá }\end{array}$ & 2006 \\
\hline $\begin{array}{l}\text { UNIOESTE/DESENVOLVIMENTO REGIONAL } \\
\text { E AGRONEGÓCIO }\end{array}$ & $\begin{array}{l}\text { Universidade Estadual } \\
\text { do Oeste do Paraná }\end{array}$ & 2003 \\
\hline $\begin{array}{l}\text { UNISC/PPGDR - DESENVOLVIMENTO } \\
\text { REGIONAL }\end{array}$ & Universidade de Santa Cruz do Sul & 1994 \\
\hline $\begin{array}{l}\text { UNIVAP/PUR - PLANEJAMENTO URBANO } \\
\text { E REGIONAL }\end{array}$ & $\begin{array}{l}\text { Universidade do } \\
\text { Vale do Paraíba }\end{array}$ & 1993 \\
\hline
\end{tabular}

FONTE: CAPES; Área Planejamento Urbano e Regional / Demografia; Cadernos de Indicadores (Ano-base 2009). 
Do ponto de vista da denominaçáo e da filiação institucional, os programas do universo AU constituem um espaço bastante homogêneo. Quatorze dos dezenove programas denominam-se de "Arquitetura e Urbanismo". Somente dois dos dezenove programas não incluem a palavra "urbanismo" em suas denominaçôes. Dezesseis dos dezenove programas integram universidades públicas. Dez programas (mais da metade) localizam-se na Região Sudeste.

No universo PUR, apenas três dos vinte programas denominam-se de "Planejamento Urbano e Regional". O termo "planejamento" aparece nas denominaçóes de sete programas e a denominação do seu objeto inclui noçôes diversas como "ambiental", "urbano e regional", "regional" e "territorial". O termo "desenvolvimento" aparece nas denominaçôes de quatorze dos vinte programas da área e a denominação do seu objeto contempla noçóes diversas como "urbano", "regional", "regional e urbano", "social" e "socioambiental". Menos da metade dos programas integram universidades públicas. Apenas três programas se localizam na Região Sudeste: dois no Estado do Rio de Janeiro, um em São Paulo.

\section{TERMOS-CHAVE}

A pesquisa empregou, essencialmente, métodos de análise de natureza qualitativa. Contudo, preliminarmente, como base para essa análise, fez-se um sumário estudo sobre a frequência ${ }^{11}$ do emprego de alguns termos-chave nos cadernos de indicadores "Proposta do Programa". Tratou-se de mera contagem de palavras, sem qualquer pretensão estatística, feita com o único objetivo de caracterizar, por contraste, o contexto terminológico do universo examinado. Para tanto, foi contado o número de mençóes feitas aos seguintes termos: ambiente e derivaçóes do termo, como ambiental; arquitetura e derivaçóes do termo, como arquitetural, arquitetônico(a); cidade; espaço e derivaçôes do termo, como espacial, espacialidade; gestáo; planejamento; política(o); regiáo e derivaçôes do termo, como regional; tecnologia e derivaçóes do termo, como tecnológico(a); território e derivaçôes do termo, como territorial, territorialidade; urbanismo e derivaçôes do termo, como urbanista, urbanístico(a); urbano(a). Dez desses termos-chave foram escolhidos simplesmente porque estấo presentes na denominação das áreas de conhecimento e de alguns programas que as integram. As exceçóes ficaram por conta dos termos politica e tecnologia, propostos com base na suposição de que poderiam discriminar ênfases em aspectos técnicos ou políticos do urbanismo/planejamento.

Antes de apresentar e comentar os resultados da pesquisa relativa aos termos-chave é importante sublinhar que os indicadores apresentados náo podem e, sobretudo, não devem ser tomados como expressão do maior ou menor envolvimento dos programas com um determinado tema. Os indicadores emolduram um contexto terminológico aberto e servem apenas para situar cada área e cada programa nesse contexto.

A Tabela 1 apresenta o somatório do número de vezes que os termos-chave aparecem nos cadernos de indicadores consultados, descriminado por área. Assim, por exemplo, o termo arquitetura (e suas derivaçóes) foi encontrado 2.313 vezes nos cadernos do universo AU e 320 vezes nos cadernos do universo PUR, totalizando
11 Obtida através do quociente entre o número total de palavras existente em cada caderno de indicadores examinado e o número de vezes em que o termo-chave foi ali mencionado. 


\subsection{3 ocorrências.}

A Tabela 1 está organizada segundo a participação relativa de cada termo, por área, frente ao número total de mençôes feitas ao mesmo. Por exemplo, o número de mençôes ao termo arquitetura (e suas derivaçôes) encontrado nos cadernos de indicadores dos programas do universo AU corresponde a $88 \%$ do total de citaçóes; o mesmo número, no universo PUR, corresponde a $12 \%$ do total de citaçóes. A distribuição relativa das citaçôes aos doze termos entre os universos AU e PUR está representada no Gráfico 1.

O contexto terminológico identificado foi subdivido em três partes ou terços, cada uma contendo quatro termos.

A parte localizada à esquerda na Tabela 1 reúne os termos (e suas derivaçóes) arquitetura [1], urbanismo [2], cidade [3] e tecnologia [4]. Mais de 60\% das citaçóes desses termos encontram-se nos cadernos do universo AU. Em outras palavras, tratase de um terço claramente dominado pelo universo AU.

A parte localizada à direita na Tabela 1 reúne os termos (e suas derivaçôes) política [9], território [10], planejamento [11] e região [12]. Mais de 60\% das citaçōes desses termos encontram-se nos cadernos do universo PUR. Trata-se de um terço claramente dominado pelo universo PUR.

A parte localizada no centro da Tabela 1 reúne os termos (e suas derivaçôes) espaço [5], urbano [6], ambiente [7] e gestão [8]. A diferença na distribuição relativa desses termos entre os universos AU e PUR é menos marcada: 59\% das citaçóes do termo espaço encontram-se nos cadernos da área AU e 41\% na área PUR; $57 \%$ das citaçôes do termo gestão encontram-se nos cadernos da área PUR e 43\% na área AU; já os termos urbano (54\% AU; 46\% PUR) e ambiente (53\% AU; 47\% PUR) apresentam distribuição semelhante nos dois universos. Trata-se de um terço onde náo se evidencia um claro domínio de nenhuma das áreas.

Tabela 1 - Termos-chave somatório das citaçóes por área

\begin{tabular}{|c|c|c|c|c|c|c|c|c|c|c|c|c|}
\hline \multirow{2}{*}{ ÁREAS } & \multicolumn{12}{|c|}{ TERMOS-CHAVE $\left(^{*}\right)$} \\
\hline & 1 & 2 & 3 & 4 & 5 & 6 & 7 & 8 & 9 & 10 & 11 & 12 \\
\hline$\sum \mathrm{AU}$ & 2313 & 1529 & 754 & 368 & 602 & 1033 & 703 & 272 & 238 & 145 & 222 & 315 \\
\hline$\sum$ PUR & 320 & 267 & 335 & 211 & 414 & 892 & 614 & 359 & 452 & 372 & 669 & 1286 \\
\hline$\sum \mathrm{AU}+\mathrm{PUR}$ & 2633 & 1796 & 1089 & 579 & 1016 & 1925 & 1317 & 631 & 690 & 517 & 891 & 1601 \\
\hline$\% \mathrm{AU}$ & 88 & 85 & 69 & 64 & 59 & 54 & 53 & 43 & 34 & 28 & 25 & 20 \\
\hline$\%$ PUR & 12 & 15 & 31 & 36 & 41 & 46 & 47 & 57 & 66 & 72 & 75 & 80 \\
\hline
\end{tabular}

(*) [1] ARQUITETURA; [2] URBANISMO; [3] CIDADE; [4] TECNOLOGIA; [5] ESPAÇO; [6] URBANO; [7] AMBIENTE; [8] GESTÃO; [9] POLÍTICA; [10] TERRITÓRIO; [11] PLANEJAMENTO; [12] REGIÃO 
Gráfico 1 - Distribuição (\%) das Palavras-Chave por Área

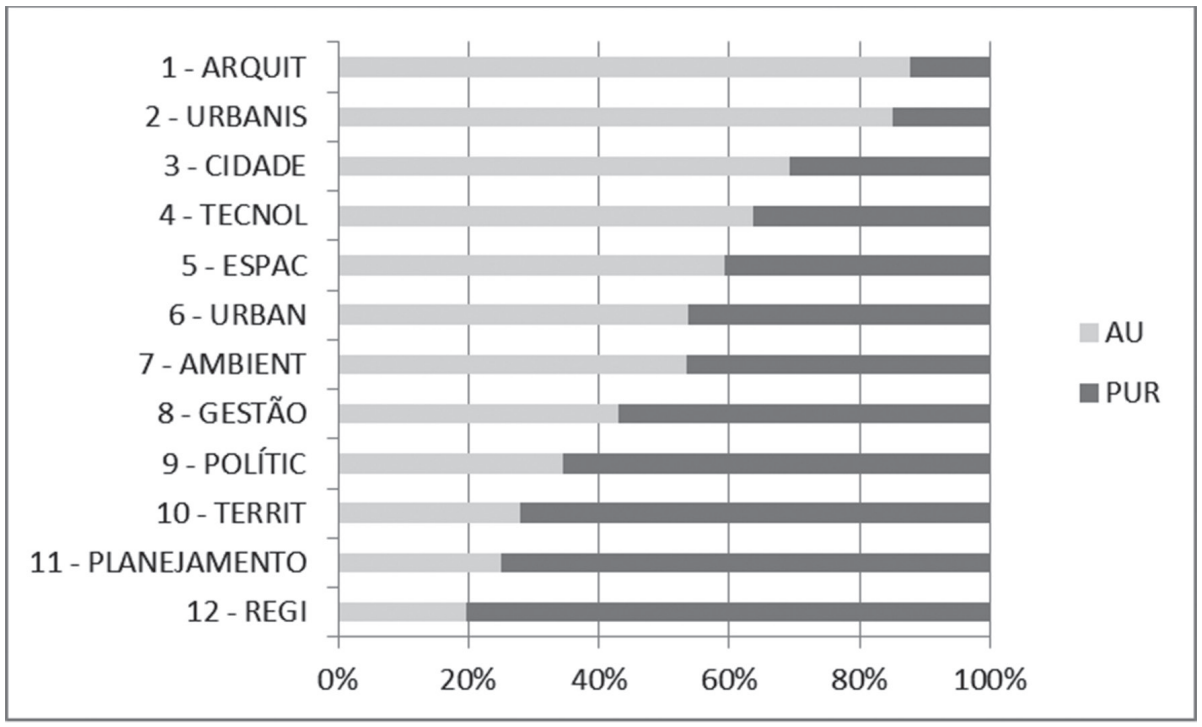

Os Quadros 3 e 4 indicam à "faixa" de frequência do emprego dos termoschave por área e por programa de pós-graduação. A faixa classificada "alta" (cinza escuro) corresponde a uma menção (ou mais) ao termo a cada 600 palavras. A faixa classificada "baixa" (cinza claro) correspondendo a uma citação (ou menos) a cada 6.000 palavras. ${ }^{12}$ Essas linhas de corte foram definidas de maneira arbitrária com a única finalidade de estabelecer algum contraste. Os casos em que não foi encontrada nenhuma menção aos termos-chave aparecem indicados pela palavra "zero" e, para efeito de discussão, foram agregados aos casos de frequência baixa.

Os termos empregados com frequência "alta" pelos programas do universo AU concentram-se claramente nos dois primeiros terços da tabela - 96\% dos casos. Seis termos reúnem $88 \%$ dos casos de frequência "alta": arquitetura, urbanismo, cidade, espaço, urbano e ambiente. Os termos tecnologia, gestão, política, território, planejamento e regiáo têm importância relativamente menor no contexto terminológico do universo AU.

Os termos empregados com frequência "alta" por programas do universo PUR, concentrados nos dois últimos terços da tabela ( $83 \%$ dos casos), têm alguma expressão também no primeiro terço ( $17 \%$ dos casos), dominado pelo universo AU. Para somar $91 \%$ dos casos de frequência "alta" o universo PUR precisa agregar nove dos doze termos analisados: cidade, espaço, urbano, ambiente, gestão, política, território, planejamento e regiāo. Os termos arquitetura, urbanismo e tecnologia têm importância relativa menor no contexto terminológico desse universo.

Em resumo, no que se refere aos termos-chave com frequência "alta", verifica-se maior dispersão na área PUR e maior concentração na área AU.
12 Uma página de tamanho A4 comporta, aproximadamente, 600 palavras escritas em corpo 11; desse ponto de vista, os limites de nossas faixas correspondem grosso modo a uma citação do termo (ou mais de uma) por página, frequência considerada "alta", e a uma citação do termo (ou menos de uma) a cada dez páginas, frequência considerada "baixa". 
U R B A N I M O VERS U S P L A N E J A M E N T O U R B A N O ?

Quadro 3 - Termos-chave / frequência das citaçóes por programa da área AU

\begin{tabular}{|c|c|c|c|c|c|c|c|c|c|c|c|c|}
\hline \multirow{2}{*}{ Programas } & \multicolumn{12}{|c|}{ Termos-chave $\left(^{*}\right)$} \\
\hline & 1 & 2 & 3 & 4 & 5 & 6 & 7 & 8 & 9 & 10 & 11 & 12 \\
\hline $\begin{array}{l}\text { PUC-Campinas/ } \\
\text { PPGU }\end{array}$ & Alta & Alta & Alta & & Alta & Alta & Alta & & & & & Alta \\
\hline $\begin{array}{l}\text { UFAL/ } \\
\text { PPGAU-DEHA }\end{array}$ & Alta & Alta & & & Alta & Alta & Alta & & & & & \\
\hline UFBA/PPGAU & Alta & Alta & Alta & & Alta & Alta & & Baixa & & & & \\
\hline UFES/PPGAU & Alta & Alta & Alta & & & Alta & & & Zero & & & \\
\hline UFF/PPGAU & Alta & Alta & Alta & & Alta & Alta & Alta & Alta & & & & \\
\hline UFMG/NPGAU & Alta & Alta & & & Alta & Alta & & & & & & \\
\hline UFPB/PPGAU & Alta & Alta & Alta & Alta & & Alta & Alta & & & Baixa & & \\
\hline $\begin{array}{l}\text { UFPEL/ } \\
\text { PROGRAU }\end{array}$ & Alta & Alta & & Alta & Alta & Alta & Alta & & Baixa & Baixa & & Alta \\
\hline $\begin{array}{l}\text { UFRGS/ } \\
\text { PROPAR }\end{array}$ & Alta & Alta & & & & Alta & & Zero & & & Baixa & \\
\hline UFRJ/PROARQ & Alta & & & & Alta & & Alta & Alta & Baixa & Baixa & & \\
\hline UFRJ/PROURB & Alta & Alta & Alta & & Alta & Alta & & & & & & \\
\hline UFRN/PPGAU & Alta & Alta & Alta & & Alta & Alta & Alta & & & Alta & & \\
\hline UFSC/PósARQ & Alta & Alta & & Alta & Alta & Alta & Alta & & & & & \\
\hline UFSC/PGAU & Alta & Alta & Alta & & Alta & Alta & Alta & & & & & Alta \\
\hline UnB/PPG-FAU & Alta & Alta & & & & & Alta & & & & & \\
\hline UPM/PPGAU & Alta & Alta & Alta & & & Alta & & Baixa & & & & \\
\hline USJT/PGAUR & Alta & Alta & Alta & Baixa & & & Baixa & Zero & Baixa & & Zero & Baixa \\
\hline USP-SP/PPGAU & Alta & Alta & Alta & Alta & Alta & Alta & Alta & & & & & \\
\hline USP-SC/PPGAU & Alta & Alta & Alta & Alta & & Alta & Alta & Alta & & & & \\
\hline $\begin{array}{l}\text { No DE } \\
\text { CASOS ALTA }\end{array}$ & 19 & 18 & 12 & 5 & 12 & 16 & 12 & 3 & 0 & 1 & 0 & 3 \\
\hline $\begin{array}{l}\text { No DE CASOS } \\
\text { BAIXA+0 }\end{array}$ & 0 & 0 & 0 & 1 & 0 & 0 & 1 & 4 & 4 & 3 & 2 & 1 \\
\hline $\begin{array}{l}\text { TOTAL / } \\
\text { TERÇO ALTA }\end{array}$ & \multicolumn{4}{|c|}{$54(53 \%)$} & \multicolumn{4}{|c|}{$43(43 \%)$} & \multicolumn{4}{|c|}{$4(4 \%)$} \\
\hline $\begin{array}{l}\text { TOTAL / } \\
\text { TERÇO BAIXA+0 }\end{array}$ & \multicolumn{4}{|c|}{$1(7 \%)$} & \multicolumn{4}{|c|}{$5(31 \%)$} & \multicolumn{4}{|c|}{$10(62 \%)$} \\
\hline
\end{tabular}

(*) [1] ARQUITETURA; [2] URBANISMO; [3] CIDADE; [4] TECNOLOGIA; [5] ESPAÇO; [6] URBANO;

[7] AMBIENTE; [8] GESTÃO; [9] POLÍTICA; [10] TERRITÓRIO; [11] PLANEJAMENTO; [12] REGIÃO 
Quadro 4 - Termos-chave / frequência das citaçôes por programa da área PUR

\begin{tabular}{|c|c|c|c|c|c|c|c|c|c|c|c|c|}
\hline \multirow{2}{*}{ Programas } & \multicolumn{12}{|c|}{ Termos-Chave $\left(^{*}\right)$} \\
\hline & 1 & 2 & 3 & 4 & 5 & 6 & 7 & 8 & 9 & 10 & 11 & 12 \\
\hline ALFA/PPGDR & Zero & Zero & & & & & & Alta & & & & Alta \\
\hline FURB/PPGDER & & & & & & & & & Alta & Alta & & Alta \\
\hline PUC-GO/MDPT & & & Alta & & Alta & Alta & Alta & & Alta & Alta & Alta & Alta \\
\hline PUC-PR/PPGTU & Alta & & Alta & Alta & & Alta & Alta & Alta & Alta & Baixa & Alta & Alta \\
\hline UCAM & Zero & & Alta & & & Alta & & & & & Alta & Alta \\
\hline UCSAL/MPA & Baixa & Baixa & & & & Alta & Alta & & & Alta & Alta & \\
\hline UCSAL & Baixa & & Alta & & & Alta & Alta & & & Alta & Alta & Alta \\
\hline UDESC & Baixa & Baixa & & & & Alta & Alta & & & Alta & Alta & Alta \\
\hline UEPB/MDR & Zero & Zero & Zero & & & & Alta & & Alta & & & Alta \\
\hline UFPE/MDU & Alta & Alta & Alta & & Alta & Alta & Alta & Alta & Alta & & Alta & \\
\hline UFRGS/PROPUR & Alta & Alta & Alta & & Alta & Alta & & & & & Alta & Alta \\
\hline UFRJ/IPPUR & Alta & Alta & Alta & & & Alta & & & Alta & Alta & Alta & Alta \\
\hline UFT & & Zero & & & & Alta & Alta & & & & & Alta \\
\hline UNAMA & & & & & & Alta & Alta & Alta & & & Alta & Alta \\
\hline UNC & Baixa & Zero & Baixa & & & & & Alta & Alta & & & Alta \\
\hline $\begin{array}{l}\text { UNIFACS/ } \\
\text { PPGDRU }\end{array}$ & & Alta & & & & Alta & Alta & & Alta & & Alta & Alta \\
\hline UFAP & & Zero & Zero & Alta & & & Alta & & & & Zero & Alta \\
\hline UNIOESTE & Zero & Baixa & & & Alta & & & & Alta & & & Alta \\
\hline UNISC/PPGDR & Zero & Zero & Baixa & & & & & & Alta & & Alta & Alta \\
\hline UNIVAP/PUR & & & & & Alta & Alta & Alta & & Alta & & Alta & Alta \\
\hline $\begin{array}{l}\text { No DE } \\
\text { CASOS ALTA }\end{array}$ & 4 & 4 & 7 & 2 & 5 & 13 & 12 & 5 & 11 & 6 & 13 & 18 \\
\hline $\begin{array}{l}\text { No DE CASOS } \\
\text { BAIXA+0 }\end{array}$ & 9 & 9 & 4 & 0 & 1 & 0 & 0 & 0 & 0 & 1 & 1 & 0 \\
\hline $\begin{array}{l}\text { TOTAL / } \\
\text { TERÇO ALTA }\end{array}$ & \multicolumn{4}{|c|}{$17(17 \%)$} & \multicolumn{4}{|c|}{$35(35 \%)$} & \multicolumn{4}{|c|}{$48(48 \%)$} \\
\hline $\begin{array}{l}\text { TOTAL / } \\
\text { TERÇO BAIXA+0 }\end{array}$ & \multicolumn{4}{|c|}{$22(92 \%)$} & \multicolumn{4}{|c|}{0} & \multicolumn{4}{|c|}{$2(8 \%)$} \\
\hline
\end{tabular}

(*) [1] ARQUITETURA; [2] URBANISMO; [3] CIDADE; [4] TECNOLOGIA; [5] ESPAÇO; [6] URBANO; [7] AMBIENTE; [8] GESTÃO; [9] POLÍTICA; [10] TERRITÓRIO; [11] PLANEJAMENTO; [12] REGIĀO

\section{PROGRAMAS DE REFERÊNCIA}

A partir do contexto terminológico descrito acima, abordou-se com maior profundidade os cadernos "Proposta do Programa” de certo número de instituições. Foram escolhidos os programas que, ou pelas notas que obtiveram na Avaliação Trienal 2007-2009, ou por sua maior experiência, podem ser definidos como "programas de referência" das duas áreas. No caso do universo AU, foram examinados os cadernos de indicadores dos sete programas que obtiveram as melhores avaliaçóes: UFRJ/PROURB e USP-SP/PPGAU (nota seis), UFBA/PPGAU, UFMG/NPGAU, UFRGS/PROPAR, UFRJ/PROARQ e USP-SC/PPGAU (nota cinco). No universo PUR, foram examinados os cadernos de indicadores dos três programas 
que obtiveram as melhores avaliaçôes: UFRJ/IPPUR (nota seis), UFPE/MDU e UFRGS/PROPUR (nota cinco). A eles foram somados, por critério de antiguidade, três dos sete programas que obtiveram nota quatro: UNISC/PPGDR, PUC-PR/ PPGTU e UNIFACS/PPGDRU.

A análise procurou compreender o posicionamento de cada programa com relação à sua própria área de conhecimento e, de modo especial, com relação à questáo disciplinar - mas sem entrar no debate sobre o significado dos diversos conceitos associados à questão, como inter, multi, pluri, transdisciplinar. Aprofundamos também o exame do posicionamento de cada programa especificamente com relação ao emprego dos termos urbanismo, cidade e planejamento. Sobre esses três termos, inicialmente, é interessante observarmos o Quadro 5, relativo aos cadernos de indicadores dos treze programas de referência analisados.

Quadro 5 - Citaçôes por termos-chavee programas selecionados / Universos AU e PUR

\begin{tabular}{|c|c|c|c|c|c|c|c|c|c|c|c|c|c|}
\hline \multirow[b]{2}{*}{ Termos-chave } & \multicolumn{7}{|c|}{ UNIVERSO AU } & \multicolumn{6}{|c|}{ UNIVERSO PUR } \\
\hline & $\begin{array}{c}\text { UFRJ } \\
\text { PROURB }\end{array}$ & \begin{tabular}{|l|} 
USP-SP \\
PPGAU
\end{tabular} & \begin{tabular}{|c|} 
UFBA \\
PPGAU
\end{tabular} & $\begin{array}{l}\text { UFMG } \\
\text { NPGAU }\end{array}$ & \begin{tabular}{|c|} 
UFRGS \\
PROPAR
\end{tabular} & $\begin{array}{c}\text { UFRJ } \\
\text { PROARQ }\end{array}$ & $\begin{array}{l}\text { USP-SC } \\
\text { PPGAU }\end{array}$ & $\begin{array}{l}\text { UFRJ } \\
\text { IPPUR }\end{array}$ & $\begin{array}{l}\text { UFPE } \\
\text { MDU }\end{array}$ & \begin{tabular}{|c|} 
UFRGS \\
PROPUR
\end{tabular} & $\begin{array}{l}\text { PUC-PR } \\
\text { PPGTU }\end{array}$ & $\begin{array}{l}\text { UNIFACS } \\
\text { PPGDRU }\end{array}$ & $\begin{array}{l}\text { UNISC } \\
\text { PPGDR }\end{array}$ \\
\hline Urbanismo & Alta & Alta & Alta & Alta & Alta & & Alta & Alta & Alta & Alta & & & Zero \\
\hline Cidade & Alta & Alta & Alta & & & & Alta & Alta & Alta & Alta & Alta & & Baixa \\
\hline Planejamento & & & & & Baixa & & & Alta & Alta & Alta & Alta & Alta & Alta \\
\hline
\end{tabular}

Segundo sugere o contexto terminológico do universo AU, os programas UFRJ/ PROURB, USP-SP/PPGAU, UFBA/PPGAU e USP-SC/PPGAU aparentemente tem maior proximidade com os temas da cidade e do urbanismo no que os programas UFMG/NPGAU, UFRGS/PROPAR e UFRJ/PROARQ. Note-se que os programas UFRGS/PROPAR e UFRJ/PROARQ denominam-se "de Arquitetura" e que, originalmente, o Programa UFMG/NPGAU também se denominava simplesmente "de Arquitetura". Note-se ainda que, segundo a linha de corte definida, nenhum dos sete programas utiliza com frequência "alta" o termo "planejamento".

No universo PUR, a terminologia empregada pelos programas UFRJ/IPPUR, UFRGS/PROPUR (em "Planejamento Urbano e Regional") e UFPE/MDU (em "Desenvolvimento Urbano") sugere maior afinidade com os temas da cidade, do urbanismo e do planejamento do que àquela relativa aos programas UNISC/PPGDR (em "Desenvolvimento Regional") e UNIFACS/PPGDRU (em "Desenvolvimento Regional e Urbano"). O Programa PUC-PR/PPGTU (em "Gestão Urbana”) ocupa uma posição intermediária nesse contexto terminológico.

\section{UNIVERSO AU}

\section{a) Proposta UFRJ/PROURB}

A Proposta insere o Programa no "campo do urbanismo" (p. 5), entendido como "campo do conhecimento" e como "campo disciplinar específico" (p. 3).

O Programa "dedica-se a formar profissionais altamente qualificados, promover a reflexão crítica, teórica e metodológica sobre o Urbanismo” (p. 3). Mais especifica- 
mente, sua atuação visa "responder à necessidade de pesquisa neste campo do conhecimento e atender à demanda de formação e capacitação docente e de profissionais habilitados a atuar nos processos de intervençáo e configuraçáo do espaço da cidade" (p. 3). Ou, ainda, busca "promover a reflexão crítica e avançar teórica e metodologicamente em nosso campo disciplinar específico" (p. 3). Mas a Proposta contempla ainda outra definição: "No campo temático em que atuamos, consideramos fundamental a interação com o nível de formação profissional em Arquitetura, que é a graduação. Tal inserção fortalece ambos os níveis de ensino e, sobretudo, permite ampliar as bases de uma reflexão sobre o campo disciplinar, bem como sobre o ensino e a pesquisa" (p. 6). Que "campo disciplinar" seria esse? Seria o urbanismo um "campo temático" no interior do "campo disciplinar" da "arquitetura" ou da "arquitetura e urbanismo"?

O Programa dispóe de um Núcleo Interdisciplinar de Pesquisas em Paisagismo (p. 12). Mas a Proposta jamais caracteriza o trabalho desenvolvido pelo Programa como sendo de natureza inter, multi, pluri ou transdisciplinar. As dissertaçóes e teses desenvolvidas pelos alunos, entretanto, podem ter "caráter interdisciplinar", situação em que se admite a co-orientação por "docente externo" ao Programa (p. 18).

A "cidade" aparece como categoria central na Proposta e, mais de uma vez, é explicitamente definida como principal objeto de estudo do Programa: "No campo disciplinar do Urbanismo, [o Programa] tem como objeto de estudo a cidade e trata de sua organização físico-espacial e da intervenção sobre o espaço urbano. Neste sentido, aborda os processos de construçáo e produçáo do espaço, seja ele projetado ou construído socialmente. Privilegia a análise da organização espacial e das teorias sobre a cidade a partir da perspectiva histórica. Trabalha o projeto urbano como prática projetual e processo dinâmico de intervenção sobre o espaço construído, considerando a interaçáo entre os diversos agentes e visando a melhoria da qualidade de vida nas cidades" (p. 3). Como se pode constatar, a Proposta aborda a cidade ao mesmo tempo como artefato e processo social, enfatizando a importância de uma "prática projetual" que envolve a interação entre "diversos agentes".

O termo "planejamento" ocupa lugar secundário na Proposta. Mas o Programa reconhece as demandas de órgáos públicos "vinculados ao planejamento e ao projeto da cidade e às questôes urbanas em geral” (p. 5) e valoriza a cooperaçáo com instituiçôes de planejamento. Como já foi observado, o termo "urbanismo" ocupa lugar central na Proposta UFRJ/PROURB, um Programa criado justamente para atender "à grande demanda existente na área do Urbanismo" (p. 3).

\section{b) Proposta USP-SP/PPGAU}

O Programa compreende em "seu escopo diferentes campos disciplinares na área de Arquitetura, Urbanismo e Design” (p. 3). Essa diversidade proporcionaria "ao aluno o contato com os vários campos de atuaçáo da área de arquitetura, urbanismo e design e a possibilidade de construir interfaces entre elas" (p. 3). O Programa "mantém, desde sua criação, o compromisso com a formação multidisciplinar do arquiteto e urbanista, com abordagem abrangente, mas que possibilita a especialização em áreas de concentração" (p. 3).

Ao apresentar seus núcleos de pesquisa, a Proposta refere-se à existência de "espaço interdisciplinar institucional de pesquisa, que congrega professores e pesquisadores no estudo da produção e apropriação do ambiente construído" (p. 6). Refere-se ainda a um "núcleo de pesquisa interdisciplinar voltado à pesquisa sobre as estruturas espa- 
ciais regionais e urbanas, abordando aspectos socioeconômicos, institucionais, tecnológicos e de organização" e também a um grupo cujo objetivo seria "promover estudos e pesquisas interdisciplinares, enfocando as culturas urbanas contemporâneas através das suas formas materiais de manifestação" (p. 6).

A "cidade", categoria importante na Proposta, parece concorre ali com as noçóes de "assentamento humano" e "ambiente construído". Por exemplo, a área de concentração "História e Fundamentos da Arquitetura e Urbanismo" tem como objetivo "promover o conhecimento científico dos processos de permanência e mudança do ambiente construído, oferecendo elementos para elaboração e crítica de projetos e intervençôes arquitetônicas e urbanísticas" (p. 5). Na Proposta, são empregadas ainda, frequentemente, as noçôes de espaço urbano e espaço construído.

O termo "planejamento" é importante no contexto terminológico da Proposta. A área de concentração "Planejamento Urbano e Regional” tem como objetivo "o estudo das bases teóricas e das práticas de intervenção na organização espacial de atividades sob a ação simultânea da regulação do mercado e do Estado", a análise dos "processos econômicos que incidem sobre a organização do espaço do âmbito local ao nacional, as políticas e práticas de intervenção no âmbito urbano e regional" e o estudo da "relação entre processo de urbanização e a formação do urbanismo e planejamento urbano no Brasil” (p. 6). O texto sugere, portanto, a existência de açóes distintas, relacionada ao urbanismo e ao planejamento. Já o termo "urbanismo" ocupa lugar relativamente secundário na Proposta; o texto manifesta clara preferência pelo uso da expressão "arquitetura e urbanismo".

\section{c) Proposta UFBA/PPGAU}

A Proposta situa o Programa no "campo da Arquitetura e Urbanismo" (p. 3), mas também o relaciona aos campos do "espaço construído" (p. 2) e "da arquitetura, do urbanismo e das artes” (p. 20). A Proposta inscreve as duas áreas de concentração do Programa, "Urbanismo" e "Conservação e Restauro", no "campo crítico e propositivo do espaço construído" (p. 2). Um dos objetivos do Programa é "a formação de doutores qualificados que possam atuar" em "Pesquisa e Ensino no campo da Arquitetura e Urbanismo" (p. 3).

A Proposta valoriza a atuação do Programa "no campo da Conservação e Restauro" (p. 3) e a "formação de doutores qualificados para o desenvolvimento de trabalhos de natureza integrada nas áreas de Urbanismo, Projeto Urbano, Planejamento Urbano e Engenharia Urbana e Ambiental, que possa atuar em Pesquisa e Ensino nestes campos disciplinares nos quais as fronteiras são cada vez mais difusas" (p. 10). Nesse contexto terminológico, portanto, urbanismo, projeto urbano, planejamento urbano e engenharia urbana e ambiental são tratados como "campos disciplinares" distintos e relativamente autônomos.

O Programa integra-se ao esforço de "salvaguarda das criaçóes do movimento moderno no campo da Arquitetura e Urbanismo" (p. 14); refere-se ainda ao "debate em estética urbana" existente "entre o campo das artes e do urbanismo" (p. 15). O Programa mostra interesse pelas "práticas e discursos produzidos em diferentes campos do conhecimento e, em particular, nas artes visuais, dança, arquitetura e urbanismo" (p. 15) e pelo "estudo das relaçôes entre cidade e cultura, entre territórios culturais e políticas urbanas, da interdisciplinaridade entre os campos da arquitetura, do urbanismo e das artes" (p. 20). A Proposta valoriza um "projeto multidisciplinar" (p. 3) desenvolvido pelo Programa, integrado à rede nacional de 
pesquisa, e aponta para a formulação de "novos projetos de cooperação nacional em áreas inovadoras ou interdisciplinares” (p. 6). Um dos laboratórios do Programa tem, entre seus objetivos, o de "ampliar as perspectivas de abordagens multidisciplinares e transversais" (p. 8) dos seus estudos.

A "cidade" é categoria importante no texto da Proposta. Uma das linhas de pesquisa do Programa trata da "história da cidade e do urbanismo" e um de seus objetivos é "formar docentes e pesquisadores capacitados teórica, metodológica, crítica e tecnicamente na análise de processos de organização do espaço construído e do território" (p. 2). Na Proposta, são empregadas ainda, com frequência, as noções de ambiente urbano e ambiente construído.

O termo "planejamento" ocupa lugar secundário na Proposta, aparecendo com algum destaque na descrição dos conteúdos de disciplinas. O termo "urbanismo", como vimos, ocupa lugar importante na Proposta, denominando inclusive uma das áreas de concentração do Programa.

\section{d) Proposta UFMg/NPGAU}

A Proposta não aborda diretamente a questão da área de conhecimento à qual se vincula o Programa. Quando da descrição de uma de suas linhas de pesquisa, denominada "Teoria e história da arquitetura e do urbanismo e suas relaçóes com outras artes e ciências", a Proposta refere-se ao "campo de saber" no qual inscreve os "problemas teóricos, históricos, analíticos e críticos da Arquitetura e do Urbanismo" (p. 3). A linha "aborda os problemas teóricos, históricos, analíticos e críticos da Arquitetura e do Urbanismo, numa perspectiva multidisciplinar, com ênfase em suas conexóes com outros campos de saberes, notadamente as ciências sociais, as ciências humanas e as artes" (p. 3). O texto refere-se sistematicamente aos problemas "da" arquitetura e "do" urbanismo, e não à "arquitetura e urbanismo", o que pode indicar uma intenção de diferenciar os dois termos no plano propriamente conceitual.

A palavra "cidade" é pouco empregada na Proposta. Uma das linhas de pesquisa do Programa, denominada "Planejamento e dinâmicas sócio-territoriais", "aborda a problemática da produção do espaço urbano e metropolitano, a atuação dos diversos agentes produtores desse espaço e suas interfaces, bem como as estruturas sócio-espaciais resultantes" (p. 3). Outra linha trata dos "problemas teóricos e práticos da produção do espaço construído, incluindo os processos de projeto, construção e interação espaço-usuários, com ênfase na aplicação de tecnologias digitais nesses processos" (p. 3). Na Proposta, são empregadas ainda, com alguma frequência, as noçóes de espaço arquitetônico e espaço habitacional.

O termo "planejamento" ocupa lugar importante na Proposta, embora mencionado com pouca frequência. O Programa oferece disciplinas denominadas "Aspectos Contemporâneos do Planejamento Urbano e Metropolitano" e "Teorias do Espaço e do Planejamento Urbano". O termo "urbanismo" é secundário nesse contexto terminológico.

\section{e) Proposta UFRGS/PROPAR}

Segundo a Proposta, o Programa teria sido um "dos primeiros centros de pesquisa brasileiros a desenvolver uma abordagem crítica da arquitetura fundada numa reflexão sobre a teoria e a prática do próprio fazer disciplinar" (p. 3). A afirmação da arquitetura como "saber" específico aparece como um dos objetivos da própria existência do Progra- 
ma: a "proposta do programa tem, desde a sua origem, o compromisso com a definiçáo e o aprofundamento de um campo próprio de investigação para a arquitetura, que embora integrando conhecimentos de campos afins (engenharias, informática, ciências sociais, ciências humanas, etc.), deles se diferencia como saber. O seu objetivo central é a construçáo de um corpo de conhecimentos, necessariamente aberto e perfectível, instalado em torno ao projeto arquitetônico como procedimento complexo" (p. 3).

As linhas de pesquisa e projetos do Programa buscam contribuir "para reafirmar o escopo central da proposta do programa, que é a reflexão sobre a teoria e a prática do fazer disciplinar" (p. 10). Noçôes como inter, multi, pluri ou transdisciplinar não são mencionadas na Proposta.

O termo "cidade" não ocupa lugar relevante na Proposta - o objeto de estudo do Programa é "a arquitetura".

O termo "planejamento" é mencionado uma única vez em todo texto - trata-se de referência à "Secretaria de Planejamento" da municipalidade de Porto Alegre. Os termos "planejamento urbano" e "planejamento urbano e regional" são ignorados. O termo "urbanismo" não tem qualquer relevância conceitual na Proposta.

\section{f) Proposta UFRJ/PROARQ}

A Proposta situa o Programa no "campo da Arquitetura" (p. 2), reivindicando uma "visão integradora e transdisciplinar" (p. 3) do seu objeto.

O Programa "tem por objetivos principais a produção e a difusão de conhecimento científico e profissional, e a formação de recursos humanos para a pesquisa e docência em Arquitetura” (p. 2). Para alcançar esses objetivos, privilegia "a atualização e a renovação constantes dos fundamentos teóricos e da prática desse campo, considerando-o ao mesmo tempo tecnológico e cultural” (p. 2). O universo que interessa ao Programa vai "do objeto arquitetônico ao urbano e paisagístico, por entender-se a integralidade e inter-relação entre essas identidades" (p.4).

Tendo em conta as "rápidas mudanças de paradigmas nas ciências", associadas "à velocidade midiática da informação e às transformaçóes do mundo atual", o "campo da Arquitetura agrega as contribuiçóes de estudiosos e pesquisadores de áreas afins" e trata da "compreensão do fenômeno arquitetônico mediante enfoques inter e transdisciplinares" (p. 2). A linha de pesquisas "Cultura, Paisagem e Ambiente Construído", por exemplo, "engloba campos de conhecimento integrados e metodologias de análise complementares incluindo a discussão da teoria, tecnologias e práticas de projeto, a etnografia e a antropologia, a fenomenologia; a avaliação pós-ocupação e a análise morfológica e ambiental" (p.4). A ampliação "dos projetos interdisciplinares em trabalhos integrados" (p. 9) é apontada como um dos fundamentos da excelência acadêmica do Programa.

Há referências ao desenvolvimento de "pesquisas interdisciplinares" por diversos Grupos de Pesquisa. Um dos objetivos do Grupo Espaço Saúde é "elaborar, testar e validar a metodologia de análise de espaços, a análise etnotopográfica, por meio da criação de ferramentas que têm base no leque interdisciplinar das ciências humanas (adaptadas à linguagem e à sensibilidade próprias a pesquisadores da área de arquitetura e urbanismo)" (p. 10). O Grupo Ambiente-Educação define-se como "de pesquisa interdisciplinar" (p. 10). A "missáo" do Grupo Qualidade do Lugar e Paisagem é "contribuir para a construção e a disseminação do conhecimento da teoria e do projeto de arquitetura e suas diversas interfaces interdisciplinares relacionadas com a concepçáo, a produçáo e a qualidade do ambiente construído" (p. 13). O Laboratório de Habitação define-se como grupo de pesquisa "com 
interaçóes multidisciplinares" (p. 13). O Grupo Projeto, Arquitetura e Sustentabilidade caracteriza-se "pela formação multidisciplinar, o que contribui para uma visão sistêmica de assuntos relacionados com a aplicação da Sustentabilidade na Arquitetura” (p. 14).

Como já foi observado, o principal objetivo do Programa é "a compreensão do fenômeno arquitetônico" (p. 2). A noção de "cidade", nesse contexto, ocupa lugar secundário. Relacionados ao estudo daquele fenômeno, entretanto, evocam-se termos como "ambiente", "ambiente construído", "paisagem", "lugar", "assentamentos humanos", "espaço urbano" e "espaço arquitetônico".

O termo "planejamento" não tem qualquer relevância conceitual na Proposta. Os termos "planejamento urbano" e "planejamento urbano e regional" são ignorados. O termo "urbanismo" igualmente não tem relevância conceitual na Proposta.

\section{g) Proposta USP-SC/PPGAU}

A Proposta emprega com frequência os termos "urbanismo" e "arquitetura e urbanismo" e os associa às noçôes de "disciplina", "campo disciplinar" e "campo profissional". Uma das linhas de pesquisa do Programa - "O Urbanismo como Disciplina: Cultura Técnica e Profissional" - busca justamente "estabelecer bases conceituais para a compreensão do urbanismo como campo disciplinar específico, enfocado a partir de suas teorias, práticas e realizações, bem como de sua cultura técnica e profissional" (p.4). O Programa faz referência às pesquisas realizadas pela área de concentraçáo "Teoria e História da Arquitetura e do Urbanismo" sobre "as trajetórias profissionais de engenheiros, arquitetos e urbanistas, envolvendo sua inserção na vida cultural do país, suas relaçóes com movimentos internacionais e sua inserção na estruturação de um campo profissional” (p. 8), que não é nomeado.

A Proposta não emprega uma única vez os termos inter, multi, pluri ou transdisciplinar, mas um dos grupos de pesquisa do Programa tem, entre seus objetivos, promover "troca e interlocução entre distintos campos do saber" (p. 22). Outro grupo, que "desenvolve pesquisas no campo da história das cidades e do urbanismo", realiza estudos sobre "trajetórias profissionais no campo da engenharia urbana e do urbanismo" (p. 23). A partir das noçōes de "Arquitetura, Urbanismo e Planning", uma das pesquisas desenvolvidas no Programa estuda justamente essas "instituiçôes e configuraçôes disciplinares” (p. 15). Há ainda referência ao fato do Programa reunir "um conjunto significativo de trabalhos vinculados ao campo das Políticas Públicas" (p. 6). Por outro lado, a "concentração de profissionais qualificados nas capitais e grandes centros" seria uma "questáo historicamente apontada como problema no campo da arquitetura e do urbanismo"; por isso, o Programa valoriza seu desempenho "na formação de quadros qualificados para atuação na escala regional” (p. 30).

A "cidade", abordada como arquitetura e processo social, é categoria central na Proposta. A linha de pesquisa "Cidades no Brasil: Problematização, Representações, Intervençôes e Políticas" busca "estabelecer bases teóricas e conceituais para compreensão da questão urbana no Brasil, a partir de sua história e de fatores sociais, econômicos, tecnológicos e culturais, enfatizando enfoques relacionados às representaçōes, às intervençôes e às políticas públicas” (p. 4). Na Proposta, são empregadas com frequência as noçóes de espaço urbano e espaço contemporâneo.

O termo "planejamento" não é evocado com frequência ao longo da Proposta, mas pesquisadores do Programa se interessam pela "história do planejamento e história das instituiçôes urbanísticas no Brasil”, pela "reavaliação das políticas públicas em 
Habitação Social no País” (p. 20). O texto refere-se ainda ao interesse do Programa em aprofundar pesquisas "na área do Urbanismo e do Planejamento Urbano" (p. 21).

O termo "urbanismo" ocupa lugar central na Proposta e aparece na denominação de duas áreas de concentração - "Arquitetura, Urbanismo e Tecnologia"; "Teoria e História da Arquitetura e do Urbanismo" - e de duas linhas de pesquisa - "Arquitetura, Urbanismo e Paisagismo no Brasil e na América Latina”; "O Urbanismo como Disciplina: Cultura Técnica e Profissional”. Como já observado, o estabelecimento de "bases conceituais para a compreensáo do urbanismo como campo disciplinar específico” é um dos principais objetivos do Programa (p. 4).

\section{UNIVERSO PUR}

\section{a) Proposta UFRJ/IPPUR}

O objetivo do Programa é "o desenvolvimento de atividades de ensino, pesquisa e extensão, em nível de pós-graduação, no campo do Planejamento Urbano e Regional, através de uma abordagem com forte conteúdo interdisciplinar e com ênfase na formaçâo básica" (p. 2), ou, ainda, "o estudo e a análise de questôes urbano-regionais" com base em "abordagem interdisciplinar" (p. 13). A Proposta refere-se também ao "caráter interdisciplinar da área de Planejamento Urbano e Regional” (p. 13). Segundo o texto, "é amplamente reconhecido que o estudo e a análise de questôes urbano-regionais não podem prescindir de uma abordagem interdisciplinar, combinando conhecimentos de Sociologia, Economia, Geografia, Urbanismo, Ciência Política e Direito” (p. 13). Disso decorre que "o desenvolvimento de estudos e pesquisas na área deve ser pautado, necessariamente, por forte conteúdo de natureza interdisciplinar” (p. 13). A organizaçâo curricular das atividades de ensino do Programa procura "enfrentar o desafio da interdisciplinaridade", incluindo "disciplinas obrigatórias de formação teórica e analítica" em distintos "campos disciplinares", especialmente, sociologia, economia e política, "em suas conexôes com a dimensão territorial dos processos sociais" (p. 13).

Entre as açôes que realizou no triênio 2007-2009 o Programa ressalta seu papel no processo de criação de um novo curso de graduação, em Gestão Pública para o Desenvolvimento Econômico e Social, definido como "um projeto inovador seja pela temática, seja pela forte interdisciplinaridade presente na grade curricular" (p. 6). O tema da interdisciplinaridade reaparece quando a Proposta justifica o fato do Programa "manter uma única área de concentração, em Planejamento Urbano e Regional”, como forma "de garantir tanto a interdisciplinaridade quanto a interaçấo entre estudos de corte mais analítico e investigaçôes com enfoques mais voltados para a intervenção" (p. 13). A noção de pluridisciplinaridade é evocada uma única vez, quando o Programa informa que demandou a disponibilização de novas vagas para concursos docentes "com perspectivas de aprofundamento da pluridisciplinaridade" (p. 14).

A "cidade" é uma categoria importante na Proposta e aparece na denominação de diversas disciplinas. A "formação acadêmica em PUR" oferecida pelo Programa articula "duas abordagens complementares: por um lado, o estudo dos processos de conformação e de estruturação sócio-espacial de cidades e regióes, e, por outro lado, o estudo sobre os processos de planejamento ou de formulação e implementação de políticas em sua dimensão sócio-territorial" (p. 13). A palavra "território" é empregada frequentemente, aparecendo em certa medida como alternativa ao uso do termo "espaço". 
As atividades de ensino do Programa, "nos diferentes níveis", estão voltada para a formação de "[i] pesquisadores e docentes de alto nível, em condiçôes de implementar programas acadêmicos de ensino e pesquisa na área do Planejamento e Desenvolvimento Urbano e Regional e, de modo mais geral, na área dos Estudos Urbanos e Regionais" e "[ii] profissionais de alto nível, capazes de atuar de maneira crítica e criativa, tanto em agências governamentais de planejamento, nos três níveis da Federação, quanto em organizaçôes não governamentais envolvidas com os processos de Planejamento e Desenvolvimento Regional, Urbano e Comunitário” (p. 14). Nota-se aí a relevância conceitual assumida pelo termo "desenvolvimento" na Proposta UFRJ/IPPUR.

O termo "planejamento" é central na Proposta e está presente na denominação de sua única área de concentração, "Planejamento Urbano e Regional", e de suas quatro linhas de pesquisa: "Planejamento, História e Cultura"; "Planejamento, Meio Ambiente e Tecnologia"; "Planejamento, Território e Desenvolvimento Regional”; "Planejamento e Estruturação Urbana e Metropolitana”. É frequente o emprego da expressão "planejamento urbano e regional"; também são empregadas expressões como "planejamento democrático", "planejamento e desenvolvimento local", "planejamento e uso do solo urbano", "planejamento e política urbana". O termo "urbanismo" não tem relevância conceitual no contexto da Proposta.

\section{b) Proposta UFPE/MDU}

A Proposta posiciona o Programa como lugar onde se relacionam, "de modo interdisciplinar, dois campos disciplinares, arquitetura e urbanismo e planejamento e gestão" (p. 2). Esta seria a "principal característica" do Programa (p. 2). Porém, a Proposta refere-se a outros "campos", como o "da Conservaçáo Integrada, campo disciplinar que se faz cada vez mais importante na gestấo dos bens patrimoniais das cidades" (p. 3), ou ainda ao "campo da morfologia da arquitetura e sintaxe espacial", ao "campo da conservação da arquitetura moderna" (p. 4), ao "campo" da história da cidade, a "campos disciplinares como geografia, antropologia e sociologia" e ao "campo temático do planejamento urbano" (p. 13) - portanto, reaparece aqui a expressão "campo temático", nesse caso concorrendo com a definiçấo do planejamento urbano como "campo disciplinar".

Segundo a Proposta UFPE/MDU, "a interdisciplinaridade constitui-se num ponto forte” (p. 2) do Programa. Nesse sentido, o Programa oferece a seus alunos um ambiente acadêmico "dinâmico e interdisciplinar" (p. 4). A Proposta valoriza o esforço desenvolvido no sentido da "interação vertical entre os níveis do Programa, o que possibilita o diálogo entre mestrandos e doutorandos, com ganhos expressivos para todos os alunos" (p. 10). Essa "interaçâo vertical" teria como um de seus propósitos justamente "o aprofundamento da inter e da transdisciplinaridade" (p. 10).

A "cidade" é categoria central e frequentemente empregada na Proposta. O termo quase sempre aparece associado a outras noçôes relacionadas à espacialidade urbana. Por exemplo, a linha de pesquisa "Projeto da Arquitetura e da Cidade", que "tem como objeto de estudo a morfologia da cidade e das edificaçôes, abordando as estruturas físicas e sociais", "incorpora estudos relativos aos aspectos formadores do espaço urbano, tendo interesse particular nos estudos morfológicos, na sintaxe espacial, na avaliação do espaço e do desenho urbano e em estudos sobre sua influência no grupo dos usuários e indivíduos" (p. 10). Essa mesma linha volta-se também "para o estudo histórico e teórico das experiências arquitetônicas e urbanas, em particular das ex- 
pressóes modernas" (p. 10). Outra linha de pesquisa, "Dinâmica e Gestão Urbana", trata das "questôes referentes à dinâmica urbana e ao planejamento e à gestão urbana, segundo os seguintes enfoques: i) abordagens sobre os processos de globalização e reestruturação produtiva e financeira da economia mundial: cidades em redes e cidades globais; ii) pobreza, desigualdade e segregação sócio-espacial; iii) novos instrumentos de descentralizaçáo político-administrativa, no planejamento e na gestão das cidades; iv) avaliação dos limites e possibilidades dos modelos de planejamento, gestão e governança urbana; v) infraestruturas urbanas, das redes sócio-técnicas e da mobilidade e acessibilidade nos transportes urbanos" (p. 10). Termos como "ambiente construído" e "ambiente urbano" também são frequentemente empregados.

O termo "planejamento" ocupa lugar central na Proposta. As expressóes "planejamento e gestão das cidades" e "planejamento e gestão urbana” são frequentemente empregados. Há referências ainda a "modelos de planejamento, gestão e governança urbana", a "Planejamento e Política dos Transportes Urbanos" e ao "planejamento urbano e territorial contemporâneo". O termo "urbanismo" igualmente ocupa lugar central na Proposta, de modo especial porque, como vimos, o Programa articula "dois campos disciplinares, arquitetura e urbanismo e planejamento e gestáo".

\section{c) Proposta UFRGS/PROPUR}

O Programa contempla "o estudo da realidade sócio-espacial brasileira e das práticas de planejamento urbano e regional, reconhecendo nesse campo uma complexidade propícia ao tratamento interdisciplinar" (p. 3). E apresenta-se como lugar onde convivem visōes "distintas, mas complementares" da "realidade sócio espacial", uma tributária de "abordagem arquitetônico-urbanística", outra da "tradição interdisciplinar da área [do planejamento urbano e regional] e das ciências sociais aplicadas de um modo geral" (p. 2). Portanto, a Proposta admite a convivência de um tratamento disciplinar (arquitetura-urbanismo) e outro interdisciplinar (planejamento urbano e regional) dos objetos de estudo do Programa.

A "cidade" é uma categoria importante na Proposta, mas é frequente também o emprego de termos como "território", "espaço urbano e regional", "espaço construído" e "ambiente construído". Segundo a Proposta, a "dimensão espacial” é o que "demarca, explícita ou implicitamente, os temas do planejamento urbano e regional de outras manifestações do planejamento" (p. 3). Com base nessa assertiva, o Programa inclui entre seus objetivos, "o estudo do planejamento urbano e regional e do urbanismo como campos de práticas e conhecimentos; o estudo do planejamento urbano e regional relacionado às inovaçôes geradas pela demanda de maior participação da sociedade na gestão pública; a abordagem da questão metropolitana e da gestão da metrópole; as territorialidades urbanas e regionais e as dinâmicas de apropriação social e econômica do espaço; a produção e apropriação históricas da cidade como resultado de expressóes culturais" (p. 3). Sublinhe-se, portanto, que o texto aborda o planejamento urbano e regional e o urbanismo como "campos de práticas e conhecimentos" distintos.

O termo "planejamento" ocupa lugar central na Proposta. O principal objetivo do Programa é a "formação de recursos humanos qualificados para a prática profissional do urbanismo e do planejamento" (p. 2). O "planejamento urbano e regional" é compreendido "como parte de um processo social maior, no âmbito do qual as práticas coletivas são atravessadas por componentes socioeconômicos, políticos e culturais, característicos da sociedade brasileira e de sua inserção no mundo globalizado" e "é 
visto como um requisito da ação político-administrativa em sociedades complexas" (p. 3). O texto refere-se ainda ao "Planejamento Urbano e Ambiental" e às relaçôes entre planejamento e "desenho urbano". O termo "urbanismo" ocupa lugar importante na Proposta, especialmente porque é conceitualmente diferenciado do termo "planejamento urbano".

\section{d) Proposta PUC-PR/PPGTU}

Um dos principais objetivos do Programa é "formar docentes qualificados para desenvolver atividades de ensino, pesquisa e extensão na área de Gestão Urbana” (p.2). O Programa define-se como "de caráter efetivamente multi e interdisciplinar" (p. 5). Suas disciplinas e pesquisas "buscam analisar os aspectos tecnológicos, ambientais, sociais, econômicos, políticos, administrativos e culturais do desenvolvimento e da gestão das cidades" e seu "corpo docente tem formação das mais variadas: administração, arquitetura e urbanismo, engenharia, planejamento urbano e regional, saneamento ambiental, economia, informática, comunicaçôes, sociologia, direito e ciência política” (p. 5).

Ao tratar da "transdisciplinaridade do conteúdo" de suas disciplinas, a Proposta enfatiza "que as dimensóes da gestão e políticas públicas, do desenvolvimento e da sustentabilidade urbana" estáo "presentes em todas as fases do curso, desde a disciplina de integração, das disciplinas complementares, das disciplinas de bases e das disciplinas avançadas, até à própria dissertação" (p. 8). Além disso, a participação de mais de um docente em cada disciplina visa "garantir uma prática interdisciplinar em sala de aula" (p. 8).

O termo "cidade" é uma categoria importante na Proposta; seu emprego, entretanto, poucas vezes é associado especificamente à dimensão espacial do objeto. Entre os objetivos gerais do Programa encontra-se a formação qualificada e a produção e disseminação de conhecimento "na área de Gestão Urbana"; a formação de "gestores públicos capazes de implementar políticas públicas e de gerenciar atividades e projetos setoriais nas cidades, a partir de uma visão integrada e sistêmica do meio urbano e do processo político-administrativo nos municípios"; e a produção de "subsídios para a melhoria da gestão das cidades" (p.2).

Embora o termo "planejamento" não apareça com relevância na definição dos objetivos e do objeto do Programa, ele é frequentemente evocado na Proposta. Uma das linhas de pesquisa do Programa denomina-se "Planejamento e projeto em espaços urbanos e regionais". O termo aparece ainda na denominação de mais de uma disciplina: "Planejamento e desenvolvimento urbano regional", "Planejamento municipal e sistemas de informaçáo", "Pesquisas contemporâneas em planejamento e gestão urbana", "Planejamento e políticas ambientais para a sustentabilidade". Já o termo "urbanismo" ocupa lugar secundário na Proposta, sendo evocado com alguma frequência em situaçóes muito precisas, quando há referência a alguma instituição.

\section{e) Proposta da UNIFACS/PPGDRU}

A Proposta não aborda diretamente a questão da área de conhecimento à qual se vincula o programa e não faz qualquer referência às noçôes inter, multi, pluri e transdisciplinar. No entanto, insere o Programa em uma "Universidade criada por professores que possuem uma longa tradição de trabalhos na área do desenvolvimento regional e urbano e que são continuamente requisitados pela administração pública municipal, estadual e federal a prestar serviços de consultoria, estudos e pesquisa” (p. 4). O corpo docente do Programa seria constituído por professores "com formação 
nas diversas áreas das ciências sociais aplicadas: geografia, economia, arquitetura e urbanismo, administração, direito, e sociologia” (p. 4).

A categoria "cidade" tem importância secundária na Proposta, embora o Programa se interesse pelo estudo dos "processos urbanos e regionais do desenvolvimento" (p. 4). O termo aparece na denominação de uma das linhas de pesquisa, "Desenvolvimento, políticas urbanas e rede de cidades". Os objetivos da linha não são especificados. As questôes relacionadas à espacialidade urbano-regional são praticamente ignoradas.

O termo "planejamento" é frequentemente evocado, mas não ocupa um lugar central na Proposta - lugar ocupado pelo termo "desenvolvimento". A principal preocupação do Programa é "construir um embasamento teórico para a reconstrução crítica do processo histórico do desenvolvimento regional, apresentando novas propostas para a solução dos problemas que limitam o crescimento econômico na região, mediante a realização de pesquisas e a definição de novas formas de viabilização econômica de programas e projetos, nas áreas de sua concentração de estudos” (p. 2).

Além de mestrado e doutorado, o Programa oferece cursos de especialização em "Planejamento Urbano e Gestão de Cidades" e em "Desenvolvimento Regional e Planejamento Ambiental". Contudo, na Proposta, o termo "planejamento urbano" não tem relevância conceitual e é empregado apenas quando o texto faz referência a alguma instituição da área; o mesmo acontece no que se refere ao uso do termo "urbanismo".

\section{f) Proposta UNISC/PPGDR}

A Proposta define o "desenvolvimento regional" como um "campo interdisciplinar" (p. 3). O Programa tem como um de seus principais objetivos, "fomentar e consolidar pesquisas, de caráter interdisciplinar, sobre temas relativos aos processos de desenvolvimento de uma regiáo" (p. 2). A própria origem do Programa estaria na busca, por parte da Universidade, de "um espaço de reflexão e pesquisa interdisciplinar sobre o desenvolvimento regional” (p. 4). A Proposta valoriza os "enfoques epistemológicos, princípios metodológicos e técnicas de abordagem próprios das disciplinas que confluem para a construção do campo interdisciplinar do desenvolvimento regional” (p. 3).

A categoria "cidade" não ocupa lugar importante na Proposta. O Programa se interessa por "temas relativos aos processos de desenvolvimento de uma regiâo", considerando primordial o estudo do "movimento das instituiçôes econômicas" e "das organizaçóes políticas da esfera estatal e da sociedade civil”, das “mudanças tecnológicas e ambientais" e das "alteraçôes próprias às esferas jurídicas e simbólicas (costumes, religião, etc.) que normatizam e orientam o universo das representaçốes dos membros de uma comunidade regional" (p. 2). Empregam-se com alguma frequência os termos "espaço", "território" e "espaço urbano e regional".

O termo "planejamento regional" é frequentemente evocado, mas a Proposta raramente menciona o termo "planejamento urbano", utilizado apenas quando há alguma referência institucional. A Proposta refere-se ao Núcleo de Planejamento Urbano e Gestáo Territorial, existente na Universidade, com o qual o Programa mantém relações de colaboração, e que "visa assessorar os municípios em temas relevantes relacionados ao planejamento de suas açôes" (p. 10). Segundo a Proposta, com base nessa colaboração o Programa envolveu-se com atividades de "planejamento do espaço urbano dos pequenos municípios da regiáo" (p. 10).

Uma das linhas de pesquisa do Programa é denominada "Desenvolvimento, Ordenamento Territorial e Meio Ambiente”. Uma das áreas de interesse do Programa 
é o estudo "das relaçóes dos homens entre si e com a natureza expressas na organização do espaço e no ordenamento do território, com ênfase na regionalização em sua diversidade de escalas e modalidades de abordagens teórico-metodológicas" (p. 3). Um dos projetos desenvolvidos pelo Programa trata de "metodologia de Planejamento Estratégico Regional”, proposta que "utiliza algumas ferramentas consagradas na gestão territorial", evolvendo "elaboração de diagnóstico, análise situacional, aplicação da matriz FOFA, definição de referenciais estratégicos e estabelecimento de macroobjetivos, estruturados em programas, projetos e açôes" (p. 10). O termo "urbanismo" não é empregado na Proposta.

\section{TERMOS PRÓXIMOS, MÚLTIPLOS SIGNIFICADOS}

O exame das propostas dos programas de referência relativiza a força de observaçôes feitas exclusivamente com base no contraste das frequências terminológicas. Por exemplo, as propostas UFMG/NPGAU e USP-SP/PPGAU não empregam com frequência "alta" o termo "planejamento", porém, como se constatou, nos dois casos o planejamento urbano ocupa um lugar conceitualmente relevante. Algo semelhante acontece como a Proposta USP-SC/PPGAU. A proposta UFRGS/PROPAR, ao contrário, emprega com frequência relativamente "alta" a palavra "urbanismo", mas suas referências ao termo são protocolares.

No exame das propostas dos programas de referência, verificou-se o emprego recorrente das noçóes de área, campo e disciplina (inter, multi, pluri, trans), termos que não foram objeto de cálculo de frequência. $\mathrm{O}$ Quadro 6 reúne as expressóes que contemplam tais noçóes, da maneira como foram citadas ao longo deste artigo.

A noção de "campo interdisciplinar" encontra clara ressonância no escopo de cinco das seis propostas do universo PUR analisadas. Esta ênfase terminológica sem dúvida envolve interpretaçóes incongruentes, aspecto cuja análise escapa aos objetivos desse artigo. O que se quer destacar é a firme perspectiva interdisciplinar revelada pelo universo PUR, por impreciso que seja o entendimento de seus integrantes com relação ao significado do termo. Nesse universo, há referências também aos termos multi, pluri e transdisciplinar.

Esse quadro revela-se mais diverso no universo AU. Três das sete propostas examinadas têm clara ênfase terminológica disciplinar. São programas que definem suas áreas de atuação como "disciplinas" ou "campos disciplinares" e, ao mesmo tempo, as contemplam desde uma perspectiva disciplinar: da arquitetura, no caso UFRGS/PROPAR, do urbanismo, no caso UFRJ/PROPURB, do urbanismo e/ou da arquitetura e urbanismo no caso USP-SC/PPGAU. Registre-se que esses três programas declaram-se abertos à integração de conhecimentos originados em "outras disciplinas". A Proposta UFRJ/PROARQ confere lugar importante às abordagens inter, multi e transdisciplinares. Comparadas às propostas acima citadas, as propostas UFBA/PPGAU, UFMG/ NPGAU e USP-SP/PPGAU não nos oferecem elementos para situá-las de maneira categórica com relação ao tema. A Proposta UFMG/NPGAU somente toma partido pela "perspectiva multidisciplinar" quando se refere a uma de suas linhas de pesquisa. A Proposta UFBA/PPGAU diferencia urbanismo e planejamento como campos disciplinares, mas evoca a existência de "fronteiras cada vez mais difusas" entre esses campos e valoriza abordagens de corte "transversal". A Proposta USP-SP/PPGAU, 
embora manifeste o compromisso do Programa com a "formação multidisciplinar do arquiteto e urbanista”, somente é assertiva com relação ao tema quando descreve o escopo "interdisciplinar" de alguns de seus núcleos de pesquisa.

As palavras área e campo aparecem muitas vezes como termos intercambiáveis, delimitando articulaçóes e fronteiras relativas a açóes, conhecimento e temas genericamente associados ao urbanismo/planejamento. Assim, por exemplo, encontram-se referências à área ou campo da arquitetura e urbanismo; à área ou campo do urbanismo, à área ou campo do planejamento urbano e regional; à área ou campo interdisciplinar; à área da engenharia urbana e ambiental e ao campo da engenharia urbana e do urbanismo. (ver Quadro 6).

Especificamente com relação à noção de campo, encontraram-se referências ao campo da arquitetura, ao campo das artes e do urbanismo; ao campo da conservaçáo, remetendo ao restauro ou à conservaçáo da arquitetura moderna; ao campo da morfologia e da sintaxe espacial; ao campo da história, remetendo à história da cidade ou à história das cidades e do urbanismo; ao campo das políticas públicas; ao campo do espaço construído. Encontraram-se também empregos mais abstratos, como: campo de estudos, campo de investigação, campo de práticas e conhecimentos, campo de saber, campo disciplinar ou interdisciplinar, campo de conhecimento, campo tecnológico e cultural, campo temático, campo de atuação.

Além de listar as noçôes que incluem os termos área, campo e disciplina, o Quadro 6 as relaciona a suas fontes, isto é, aos universos AU e PUR. Desse ponto de vista, observa-se que, entre as sessenta e seis noçôes listadas, apenas uma foi empregada precisamente com o mesmo sentido e acepção nos dois universos: trata-se da referência ao urbanismo como disciplina. De fato, embora encontradas nos universos AU e PUR, os conteúdos precisos das noçóes de área, campo, campo da história, campo deldo conhecimento, campo disciplinar e campo temático não se referem ao mesmo objeto. As noçóes genéricas de campo de investigação, campo de saber e campo de atuação aparecem relacionadas ao universo AU. As noçóes de campo de estudos, campo de práticas e campo interdisciplinar aparecem relacionadas ao universo PUR.

Um viés do autor certamente pode ter interferido nessas observações. No entanto, não nos parece um exagero concluir que os múltiplos conteúdos e sentidos atribuídos ao termo campo, envolvendo objetos e âmbitos distintos (arquitetura, arquitetura e urbanismo, arte, conhecimento, dança, desenvolvimento regional, disciplina, economia, geografia, história, planejamento, planejamento urbano, planejamento urbano e regional, políticas públicas, práticas, saber, urbanismo, etc.), podem ser entendidos como "marcas" das visôes particulares de cada programa em relação ao contorno do(s) espaço(s) no qual se inserem e às articulaçốes que priorizam no interior daquele(s) espaço(s). Por exemplo: um programa se situa no "campo da arquitetura" e adota uma abordagem disciplinar; outro, posicionado no mesmo "campo", enfatiza uma abordagem interdisciplinar. Outro exemplo: um programa diferencia urbanismo e planejamento urbano como campos disciplinares; outro desconhece o termo urbanismo e enfatiza questóes relativas ao desenvolvimento urbano. Enfim, os diversos âmbitos, objetos e sentidos atribuídos ao termo campo em alguma medida correspondem às diferentes posiçóes ocupadas pelos programas nos universos AU e PUR - onde os programas ora ocupam um determinado espaço, ora outro; ora estabelecem relaçôes de cooperação, ora de competição. 
Quadro 6 - Empregos das noçôes de área, campo e disciplina

\begin{tabular}{|c|c|c|c|c|c|}
\hline Noçóes & $\mathbf{A U}$ & PUR & NOÇÓES & $\mathbf{A U}$ & PUR \\
\hline área da engenharia urbana e ambiental & & & campo disciplinar - antropologia & & \\
\hline área das ciências sociais aplicadas & & & campo disciplinar - arq. e urb. & & \\
\hline área de arquitetura e urbanismo & & & campo disciplinar - conserv. integrada & & \\
\hline área de arquitetura, urbanismo e design & & & $\begin{array}{l}\text { campo disciplinar - energia } \\
\text { urbanismo e ambiental }\end{array}$ & & \\
\hline área de gestão urbana & & & campo disciplinar - geografia & & \\
\hline área do desenvolvimento regional e urbano & & & $\begin{array}{l}\text { campo disciplinar - planejamento } \\
\text { e gestáo }\end{array}$ & & \\
\hline área do plan. e desenv. urbano e regional & & & $\begin{array}{c}\text { campo disciplinar - planejamento } \\
\text { urbano }\end{array}$ & & \\
\hline área do planejamento urbano & & & campo disciplinar - projeto urbano & & \\
\hline área do planejamento urbano e regional & & & $\begin{array}{l}\text { campo disciplinar e profissional - } \\
\text { arquitetura e urbanismo }\end{array}$ & & \\
\hline área do projeto urbano & & & $\begin{array}{c}\text { campo disciplinar e profissional - } \\
\text { urbanismo }\end{array}$ & & \\
\hline área do urbanismo & & & campo disciplinar - urbanismo & & \\
\hline área do urb. e do planejamento urbano & & & $\begin{array}{l}\text { campo do conhecimento } \\
\text { - urbanismo }\end{array}$ & & \\
\hline área dos estudos urbanos e regionais & & & campo do espaço construído & & \\
\hline área interdisciplinar & & & $\begin{array}{l}\text { campo do planejamento } \\
\text { urbano e regional }\end{array}$ & & \\
\hline campo da arquitetura & & & campo do urbanismo & & \\
\hline campo da arquitetura e urbanismo & & & $\begin{array}{c}\text { campo interdisciplinar } \\
\text { - desenvolvimento regional }\end{array}$ & & \\
\hline campo da arq., do urbanismo e das artes & & & $\begin{array}{c}\text { campo interdisciplinar } \\
\text { - planejamento urb. e regional }\end{array}$ & & \\
\hline campo da conserv. da arq. moderna & & & $\begin{array}{c}\text { campo tecnológico e cultural - } \\
\text { arquitetura }\end{array}$ & & \\
\hline campo da conservação e do restauro & & & $\begin{array}{c}\text { campo temático } \\
\text { - planejamento urbano }\end{array}$ & & \\
\hline campo da engenharia urb. e do urbanismo & & & campo temático - urbanismo & & \\
\hline campo da história da cidade & & & $\begin{array}{l}\text { campos afins - engenharias, } \\
\text { informática, ciências sociais }\end{array}$ & & \\
\hline $\begin{array}{l}\text { campo da hist. das cidades } \\
\text { e do urbanismo }\end{array}$ & & & $\begin{array}{c}\text { campos de atuação área arquitetura, } \\
\text { urburnismo, design }\end{array}$ & & \\
\hline $\begin{array}{l}\text { campo da morfologia da arquitetura } \\
\text { e sintaxe espacial }\end{array}$ & & & $\begin{array}{c}\text { campos de conhecimento } \\
\text { integrados } \\
\end{array}$ & & \\
\hline campo das artes e do urbanismo & & & $\begin{array}{l}\text { campos disciplinares } \\
\text { de fronteiras difusas }\end{array}$ & & \\
\hline campo das políticas públicas & & & disciplina - administração & & \\
\hline $\begin{array}{l}\text { campo de estudo (realidade } \\
\text { sócio-espacial e planejamento) }\end{array}$ & & & disciplina - arquitetura e urbanismo & & \\
\hline campo de investigaçáa (arquitetura) & & & disciplina - arquitetura & & \\
\hline $\begin{array}{l}\text { campo de práticas e conhecimentos } \\
\text { (planejamento urbano e regional) }\end{array}$ & & & disciplina - ciência política & & \\
\hline $\begin{array}{l}\text { campo de práticas e } \\
\text { conhecimentos (urbanismo) }\end{array}$ & & & disciplina - direito & & \\
\hline campo de saber (arquitetura e urbanismo) & & & disciplina - economia & & \\
\hline campo de saber (artes) & & & disciplina - geografia & & \\
\hline campo de saber (ciências humanas) & & & disciplina - sociologia & & \\
\hline campo de saber (ciências sociais) & & & disciplina - urbanismo & & \\
\hline
\end{tabular}


Com relaçáo ao emprego das noçóes de urbanismo e planejamento urbano, os programas do universo AU sem dúvida constituem um espaço mais homogêneo. Isso provavelmente se deve, entre outras razões, ao fato desse universo ter estreitos vínculos com cursos de graduação em arquitetura e urbanismo e, portanto, com a formação profissional de um contingente importante de operadores do urbanismo/planejamento urbano. Ressalte-se que esses cursos de graduação em arquitetura e urbanismo, de modo geral, organizam-se em torno de uma "competência para o projeto" um tanto alheia à "competência para o planejamento e gestão".

Entre os programas de referência analisados, a Proposta UFRGS/PROPAR é a que melhor representa um espaço no qual os termos urbanismo e planejamento urbano têm pouca relevância conceitual. Ao que parece, em torno dessa abordagem articula-se uma posição importante na área $\mathrm{AU}$, da qual se aproxima, por exemplo, a Proposta UFRJ/PROARQ. Porém, também nesse caso aparecem diferenças significativas. As propostas UFRGS/PROPAR e UFRJ/PROARQ contemplam um mesmo objeto de conhecimento, a arquitetura, ou o fenômeno arquitetônico. Contudo, diferente da Proposta UFRGS/PROPAR, a competência para o projeto reivindicada pela Proposta UFRJ/PROARQ apoia-se decisivamente em abordagem inter/transdisciplinar, posicionamento que, desse ponto de vista, a aproxima de temas característicos da "competência para o planejamento e gestáo".

Outra posição ou espaço articulado pelo universo AU está bem representado pela Proposta UFRJ/PROURB. O urbanismo, ali, é um "campo disciplinar" estreitamente vinculado à "competência para o projeto", mas que se interroga sobre a possibilidade da "arquitetura" (campo temático ou disciplina autônoma) dar conta da cidade como objeto de estudo e de intervençáo. Desse ponto de vista, configura-se um espaço aberto ao diálogo com a "competência para o planejamento e gestão".

Entre esses dois posicionamentos articula-se outro, de fronteiras imprecisas, quase sempre referido à "arquitetura e urbanismo", representado nas propostas UFBA/PPGAU, UFMG/NPGAU e USP-SC/PPGAU. Trata-se de um espaço que de alguma maneira "integra" as duas perspectivas antes caracterizadas. A Proposta USP-SP/PPGAU situa-se próxima desse espaço, mas, ao abrigar diversas áreas de concentraçáo, inclusive em planejamento urbano e regional, parece querer transbordá-lo. Aliás, as propostas desses quatro programas nos remetem a tema que não foi tratado neste artigo, relativo à questão da filiação institucional. Talvez porque não encontrem "concorrência" no interior de suas instituiçóes, esses programas contemplam um amplo leque de competências. Ao contrário do que acontece nos casos UFRJ/PROARQ e UFRJ/PROURB, programas que em alguma medida concorrem entre si e com UFRJ/IPPUR; e UFRGS/PROPAR, programa que em alguma medida concorre com UFRGS/PROPUR. A proposta UFPE/MDU, um outro exemplo, igualmente contempla ampla gama de temas e competências, relacionadas à arquitetura, ao urbanismo, ao planejamento, à gestão e ao desenvolvimento urbano.

No universo PUR, apenas as propostas UFPE/MDU e UFRGS/PROPUR estabelecem uma clara distinção entre "urbanismo" e "planejamento urbano". Os dois programas têm estreitos vínculos com cursos de graduação em arquitetura e urbanismo. Define-se aí um espaço do universo PUR no qual os termos urbanismo e planejamento identificam campos "disciplinares" (UFPE/MDU) ou "de práticas e conhecimentos" (UFRGS/PROPUR) relativamente autônomos. Trata-se de posição onde coabitam 
reivindicaçóes de competência para o projeto e para o planejamento e gestão, próxima da posição ocupada no universo AU pela Proposta UFRJ/PROURB.

Outro espaço está bem representado pela Proposta UFRJ/IPPUR. Entre os programas de referência examinados, trata-se da única Proposta claramente presidida pela "competência para o planejamento e gestáo". Desenha-se aí um espaço direcionado ao planejamento (sem adjetivos), ao planejamento urbano e regional, ao "desenvolvimento" e às questóes urbanas e regionais. Trata-se de abordagem que, embora reconheça a importância dos vínculos entre planejamento e urbanismo, somente circunstancialmente se interessa pela "competência para o projeto".

A Proposta PUC-PR/PPGTU representaria um terceiro espaço, delimitado a partir da noçáo de "gestáo urbana", para o qual o planejamento também ocupa lugar importante. O escopo conceitual desse Programa o configura como uma espécie de variante "especializada" dos espaços mais abrangentes acima caracterizados. O mesmo se poderia dizer sobre as propostas UNISC/PPGDR e UNIFACS/PPDRU, que configuram um espaço claramente direcionado para os "estudos regionais" ou "urbanos e regionais", onde a presença do planejamento parece circunstancial.

Do ponto de vista do universo AU, e no contexto analisado, o termo "urbanismo" identifica uma disciplina autônoma e, outras vezes, um campo temático da "arquitetura e urbanismo". Em termos prospectivos, descortina-se nesse universo uma possibilidade de divergência entre os que subordinam o destino dessa disciplina (ou desse campo temático) à competência para o projeto e os que buscam maior abertura em direção aos processos de planejamento e gestão. Por outro lado, o universo AU tende a ignorar o termo "planejamento urbano" e revela pouco ou nenhum interesse por esse campo como domínio "complementar" ao urbanismo. Já no universo PUR, a julgar pelas propostas examinadas, o termo "urbanismo" pode se tornar irrelevante: em 2009, cinco dos vinte programas desse universo não o empregaram uma única vez. A valorização conceitual desse termo ficou por conta de um pequeno número de programas, historicamente vinculados às questóes do planejamento urbano ou a cursos de graduação em arquitetura e urbanismo. Contudo, segundo o estudo realizado, aparentemente o maior desafio do universo PUR é sua tendência a ignorar a própria noção de "planejamento urbano". Em 2009, poucos programas deram relevo conceitual ao termo. Não por acaso a palavra "desenvolvimento" está presente na denominação de $70 \%$ dos programas desse universo, preferência que encontra correspondência em propostas direcionadas ao estudo de processos de transformação social e/ou territorial para as quais as questôes relativas ao planejamento têm presença circunstancial.

No início deste artigo supôs-se que o trânsito entre campos epistêmicos distintos era constitutivo da experiência do urbanismo/planejamento no Brasil. O obscurecimento das diferenças existentes entre competências para o projeto e para o planejamento e gestáo de fato parece alimentar concepçôes e competiçôes incongruentes também no âmbito da pós-graduação. Diante desse quadro, o esclarecimento e a afirmação das diferenças indicam os melhores caminhos para a aproximação de experiências cognitivas complementares. Ao mirar uma "nova posiçáo", talvez se descortine um percurso onde quase todos possam se mover ganhando.
João Farias Rovati é arquiteto e urbanista; mestre em Planejamento Urbano e Regional pela Universidade Federal do Rio de Janeiro (UFRJ); diploma de Estudos Aprofundados (DEA) em Arquitetura e Urbanismo e doutor em Arquitetura e Urbanismo pela Universidade de Paris-8; professor do Programa de Pós-Graduação em Planejamento Urbano e Regional da Universidade Federal do Rio Grande do Sul (PROPUR/UFRGS), Brasil. E-mail: rovati.ufrgs@ gmail.com. 


\section{REFERÊNCIAS BIBLIOGRÁFICAS}

BOURDIEU, P. Espace social et pouvoir symbolique (1986). In: BOURDIEU, P. Choses dites. Paris: Éditions de Minuit, 1987. p. 147-166.

COHEN, J. L. Objetos singulares y ciudades singulares. En torno al "Gran París”. In: BELIL, M.; BORJA, J.; CORTI, M. (Ed.). Ciudades, una ecuación impossible. Buenos Aires: Café de las Ciudades, 2012. p. 169-180.

LAUGIER, R. Les formations d'urbaniste dans cinq pays européens: Allemagne, Espagne, Italie, Pays-Bas et Royaume-Uni. Paris: Bureau des Réseaux Professionnels de la Direction Générale de l'Urbanisme, de l'Habitat et de la Construction, Ministère de l'Equipement, des Transports, de l'Aménagement du Territoire, du Tourisme et de la Mer. avril 2005. Disponível em: <http:// www.cdu.urbanisme.equipement.gouv.fr/IMG/pdf/rapportlaugier_cle5c9515.pdf>. Acesso em: 12 maio 2013.

MARTINS, J. D. As regras da metrópole. Campo urbanístico e ordem social na Região Metropolitana de São Paulo. Tese (Doutorado). Instituto de Ciências Sociais, UnB. Brasília, 2006.

NOVICK, A. Planes realizados y proyectos inconclusos en la construcción de la ciudad moderna. Buenos Aires, 1900-1940. Tese (Doctorado). Buenos Aires: Universidad de San Andrés, 2007. $418 \mathrm{p}$.

RAPOSO, M., A. Diseño urbano. Indagaciones genealógicas y perfiles institucionales. Diseño Urbano y Paisaje. Año 3, n. 8. Julio de 2006.

RIGOTTI, A. M. Las invenciones del urbanismo en Argentina (1900-1960). Inestabilidad de sus representaciones científicas y dificultades para su profesionalización. Tese (Doutorado). Facultad de Arquitectura, Planeamiento y Urbanismo, Universidad Nacional de Rosario. Rosário (Argentina), 2005.

SOUZA, M. L. Mudar a cidade. Uma introdução crítica ao planejamento e à gestão urbanos. Rio de Janeiro: Bertand Brasil, 2002.

\section{CORPUS}

CAPES. ÁREA DE ARQUITETURA E URBANISMO. CADERNOS DE INDICADORES.

PROPOSTA DO PROGRAMA. Disponível em: <http://conteudoweb.capes.gov.br/ conteudoweb/CadernoAvaliacaoServlet?acao=filtraArquivo\&ano=2009\&codigo_ ies $=\&$ area $=29>$. Acesso em 12 maio 2013.

CAPES. ÁREADEPLANEJAMENTOURBANOEREGIONAL/DEMOGRAFIA. CADERNOS DE INDICADORES. PROPOSTA DO PROGRAMA. Disponível em: <http://conteudoweb.capes.gov.br/conteudoweb/CadernoAvaliacaoServlet?acao=filtraArquivo $\&$ ano=2009\&codigo_ies $=\&$ area $=30>$. Acesso em: 12 maio 2013.

A B S T R A C T The use of the terms urbanismo and planejamento urbano is frequently very ambiguous. This article discusses the expression of this ambiguity in the Brazilian post-graduation setting. The hypothesis is that the problem conceals the existence of different epistemic fields, generating inconsistent divergences that hinder the cooperation among fields of knowledge and professions that are not opposed, but in fact, complementary.

K E Y W O R D S epistemic fields, knowledge, professions. 